\title{
Cold and Exercise: Therapeutic Tools to Activate Brown Adipose Tissue and Combat Obesity
}

\author{
Carmem Peres Valgas da Silva ${ }^{1,2}$, Diego Hernández-Saavedra $\left.{ }^{1,2}{ }^{(}\right)$, Joseph D. White ${ }^{1,2}$ and \\ Kristin I. Stanford ${ }^{1,2, *}$ \\ 1 Dorothy M. Davis Heart and Lung Research Institute, The Ohio State University Wexner Medical Center, \\ Columbus, OH 43210, USA; Carmem.PeresValgasDaSilva@osumc.edu (C.P.V.d.S.); \\ Diego.Hernandez-Saavedra@osumc.edu (D.H.-S.); joeywhite2@gmail.com (J.D.W.) \\ 2 Department of Physiology and Cell Biology, The Ohio State University Wexner Medical Center, Columbus, \\ OH 43210, USA \\ * Correspondence: Kristin.Stanford@osumc.edu; Tel.: +1-614-247-8287
}

Received: 28 December 2018; Accepted: 4 February 2019; Published: 12 February 2019

check for updates

\begin{abstract}
The rise in obesity over the last several decades has reached pandemic proportions. Brown adipose tissue (BAT) is a thermogenic organ that is involved in energy expenditure and represents an attractive target to combat both obesity and type 2 diabetes. Cold exposure and exercise training are two stimuli that have been investigated with respect to BAT activation, metabolism, and the contribution of BAT to metabolic health. These two stimuli are of great interest because they have both disparate and converging effects on BAT activation and metabolism. Cold exposure is an effective mechanism to stimulate BAT activity and increase glucose and lipid uptake through mitochondrial uncoupling, resulting in metabolic benefits including elevated energy expenditure and increased insulin sensitivity. Exercise is a therapeutic tool that has marked benefits on systemic metabolism and affects several tissues, including BAT. Compared to cold exposure, studies focused on BAT metabolism and exercise display conflicting results; the majority of studies in rodents and humans demonstrate a reduction in BAT activity and reduced glucose and lipid uptake and storage. In addition to investigations of energy uptake and utilization, recent studies have focused on the effects of cold exposure and exercise on the structural lipids in BAT and secreted factors released from BAT, termed batokines. Cold exposure and exercise induce opposite responses in terms of structural lipids, but an important overlap exists between the effects of cold and exercise on batokines. In this review, we will discuss the similarities and differences of cold exposure and exercise in relation to their effects on BAT activity and metabolism and its relevance for the prevention of obesity and the development of type 2 diabetes.
\end{abstract}

Keywords: brown adipose tissue; cold; exercise; glucose; lipids; phospholipids; 12,13-diHOME; FGF21; VEGF; obesity

\section{Introduction}

The overall prevalence of obesity has increased dramatically over the last several decades [1,2]. The World Health Organization (WHO) has reported that more than 1.9 billion adults around the world are overweight and nearly one-third of the population is obese [3]. Obesity is a consequence of an altered energy balance in which energy intake exceeds energy expenditure [4,5]. This imbalance results in an increased accumulation of adipose tissue and impairments in glucose and lipid metabolism [68]. Obesity is strongly associated with several comorbidities including type 2 diabetes (T2DM), cardiovascular disease, certain cancers [9,10], and an increased risk of mortality [11], thus, there is a great need for effective therapies to prevent and treat obesity and its associated comorbidities [12]. 
Brown adipose tissue (BAT) is an important target to combat obesity and metabolic disease. BAT is a thermogenic tissue that consumes substantial amounts of glucose and fatty acids as fuel for thermogenesis and energy expenditure [13-15]. BAT is innervated by both sympathetic and sensory nerves and is characterized by small, multilocular lipid droplets, a high number of mitochondria, and an abundant expression of the mitochondrial protein, uncoupling protein 1 (UCP1). When activated, UCP1 uncouples mitochondrial respiration from adenosine-5'-triphosphate (ATP) synthesis [16,17], increasing the proton leak across the inner mitochondrial membrane and releasing the proton motive force as heat rather than driving ATP synthase [18]. BAT maintains a high oxidative metabolic capacity, and when it is highly active, it exerts beneficial metabolic effects on obesity, insulin resistance, and atherosclerosis [19-21].

There are several established mechanisms that influence BAT activity and metabolism, including cold exposure and exercise [22,23]. These two stimuli have distinct effects on BAT. Cold exposure is the most well-studied means to activate BAT, as the primary role of BAT is to mediate non-shivering thermogenesis in mammals [22]. Cold exposure leads to the activation of the sympathetic nervous system (SNS), causing release of norepinephrine from sympathetic nerves and activation of the $\beta$-adrenergic receptor ( $\beta$-AR). This stimulates cyclic adenosine monophosphate (cAMP)-dependent signaling pathways and results in increased fuel uptake and oxidation for heat generation by UCP1 [24]. Thus, cold-activated BAT increases excess fuel uptake and energy expenditure that likely impacts obesity and insulin resistance.

Exercise enhances insulin sensitivity, improves glucose tolerance, and reduces circulating lipids, all of which improve metabolic health. Exercise causes adaptations to several tissues in the body including skeletal muscle, the cardiovascular system, white adipose tissue (WAT), and BAT [25-28]. The effect of exercise on BAT, however, has provided some conflicting data with some studies indicating an increase in BAT activity [27,29-31], and some demonstrating a decrease in BAT activity [32-34]. In contrast to cold exposure, exercise itself is a thermogenic activity, so it is unlikely that exercise would further increase the thermogenic function of BAT [35,36]. The SNS is also stimulated by exercise, so it is possible that exercise-induced $\beta$-adrenergic receptor stimulation activates BAT, particularly given that recent studies have demonstrated that exercise is capable of increasing the sympathetic tone and vascularization of BAT [37,38]. Although this is an interesting hypothesis, it has not been experimentally investigated [37]. While the thermogenic activity of BAT is likely not the primary response to exercise, there are other exercise-induced adaptations to BAT that may contribute to the beneficial effects on metabolic health.

Thus, in this review, we will discuss the current literature examining the effects of cold exposure and exercise on BAT activation and energy expenditure with a focus on how they impact glucose metabolism, lipid metabolism, structural lipids, and BAT-secreted factors (batokines) in terms of their similarities, differences, and potential relevance for the prevention of obesity and T2DM (Figure 1). 


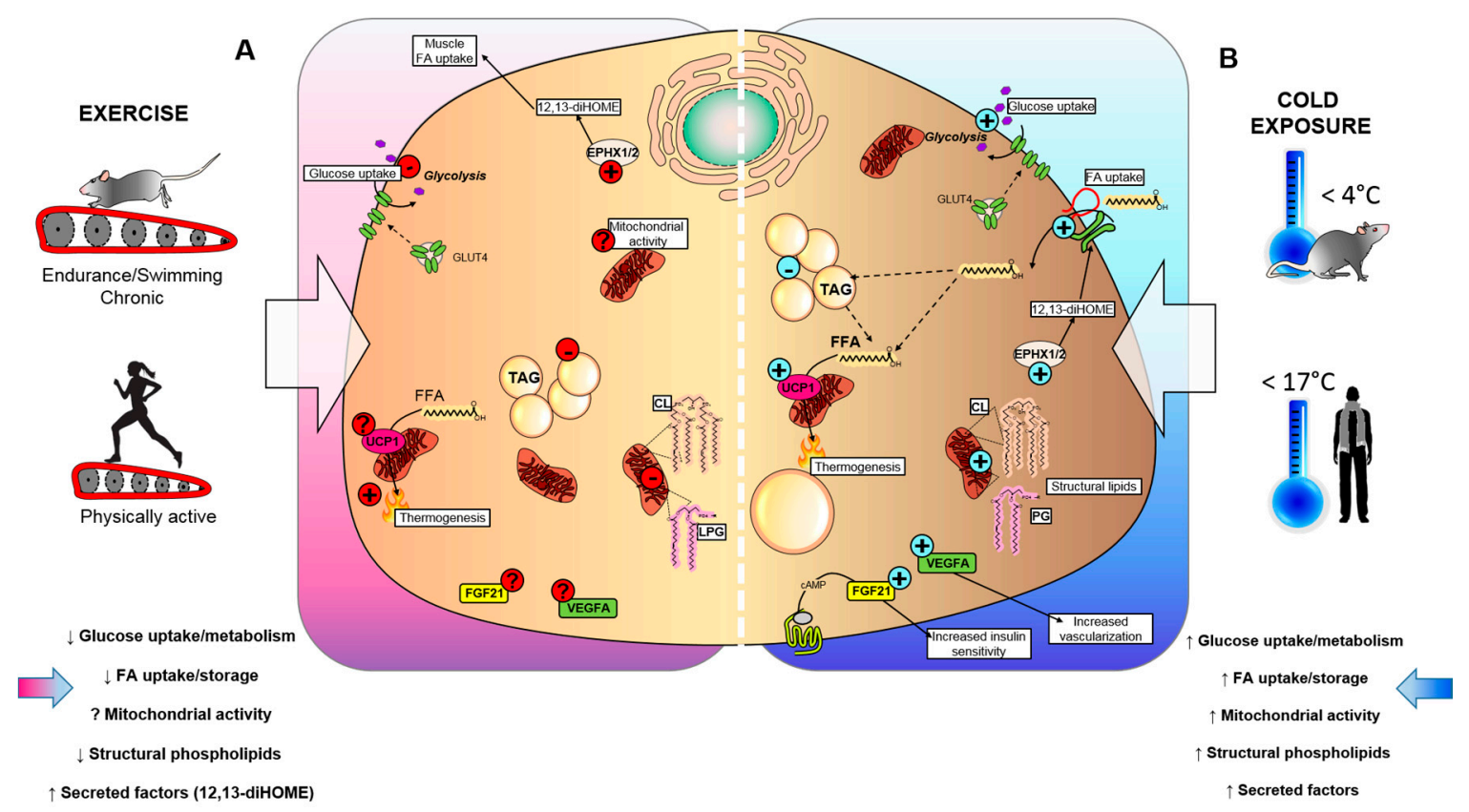

Figure 1. Effects of cold exposure and exercise on BAT. (A) Exercise and (B) cold exposure effects on BAT metabolism can cause the release of batokines, which act in an autocrine, paracrine, or endocrine manner to influence metabolic health. (A) Exercise reduces insulin-stimulated glucose uptake in BAT, suppresses triglyceride (TAG) accumulation, and lowers mitochondrial lipids, such as cardiolipin (CL) and lysophosphatidylglycerol (LPG), which could affect the thermogenic capacity of BAT. Conversely, exercise training stimulates epoxide hydrolase 1 and $2(E p h \times 1 / 2)$, and increases the synthesis of the lipokine 12,13-diHOME. The effects of exercise on mitochondrial activity, fibroblast growth factor 21 (FGF21) and vascular endothelial growth factor A (VEGFA) production are unknown. (B) Exposure to cold temperatures stimulates insulin-stimulated glucose uptake in BAT, synthesis of CL and LPG, and secretion of batokines FGF21 and VEGFA that lead to increased insulin sensitivity and tissue vascularization. Additionally, cold exposure increases the synthesis of 12,13-diHOME, which can act in an autocrine manner to promote fatty acid uptake in BAT, ultimately leading to increased TAG and UCP1-mediated thermogenesis.

\section{The Role of BAT in Glucose Metabolism in Response to Cold and Exercise}

Among the many fuel sources of BAT, glucose is a major contributor and plays an important role in BAT homeostasis [20,22]. Other fuel sources for BAT include dietary and non-esterified fatty acid (FA), as well as glutamate, which can directly or indirectly stimulate thermogenesis [15]. Activated BAT can use glucose and fatty acids as fuel for thermogenesis, enhancing overall energy expenditure in rodents and humans $[19,23]$, and increased BAT activity is associated with lower blood glucose levels in humans [39]. Cold exposure and exercise have distinct effects on glucose uptake and metabolism in BAT; in the section below, we will discuss these effects.

\subsection{Cold Exposure Increases Glucose Metabolism in BAT}

Cold exposure is a powerful stimulus to increase glucose uptake in BAT. Both acute (4-48 h) and chronic (10 days) cold exposure increased glucose uptake and improved insulin sensitivity by increasing the glucose transporter type 4 (GLUT4) expression or clearing serum triacylglycerol (TAG) in BAT in rodents $[19,40-43]$. This increase in glucose uptake is largely due to increased expression of genes and proteins involved in glucose metabolism and insulin signaling. A previous study showed that in a pathophysiological condition, 24-h cold exposure stimulates BAT to clear TAG from circulation, which is associated to an insulin-resistant state [19] (Table 1). Cold exposure also increased glucose uptake in BAT of obese, glucose-intolerant mice (hypertriglyceridemic Apoa5 deficient mice). The cold-activated increase in BAT glucose uptake was greater than in all other tissues (brain, heart, 
liver, WAT, and skeletal muscle) combined $[19,43]$. Together these data indicate that cold exposure is a powerful stimulus to increase glucose uptake and insulin sensitivity in BAT (Figure 1).

In humans, BAT activity is measured by fluorodeoxyglucose $\left({ }^{18} \mathrm{FDG}\right)$ uptake by positron emission tomography-computed tomography (PET-CT). Studies in humans have shown that cold exposure for $2 \mathrm{~h}\left(16{ }^{\circ} \mathrm{C}-18{ }^{\circ} \mathrm{C}\right)$ [44-46], 5-8 $\mathrm{h} \mathrm{[47],} \mathrm{or} 10$ days [48,49] all increase glucose uptake in BAT (Table 2). In fact, human studies have shown that cold-activated glucose uptake in BAT is greater than insulin-stimulated glucose uptake in BAT [45]; cold exposure increased glucose uptake in BAT up to 12-fold, while insulin stimulation increased glucose uptake only 5-fold in BAT [45]. The increase in cold-activated BAT glucose uptake is correlated with improved whole-body glucose disposal and insulin sensitivity in healthy adults [44], obese adults [49,50], and in patients with T2DM [49]. These data indicate that acute and chronic cold exposure increase glucose uptake and insulin signaling in BAT in both rodents and humans (Figure 1). 
Table 1. Effect of cold and exercise on BAT metabolism in mice.

\begin{tabular}{|c|c|c|c|c|c|c|c|c|}
\hline $\begin{array}{l}\text { Therapeutic } \\
\text { Strategy }\end{array}$ & Reference & Treatment & Duration & $\begin{array}{c}\text { Animal } \\
\text { Model }\end{array}$ & $\begin{array}{l}\text { Experimental } \\
\text { Challenge }\end{array}$ & $\begin{array}{l}\text { BAT Glucose } \\
\text { Metabolism }\end{array}$ & $\begin{array}{l}\text { BAT Lipid } \\
\text { Metabolism }\end{array}$ & $\begin{array}{l}\text { BAT Mitochondrial } \\
\text { Activity }\end{array}$ \\
\hline $\begin{array}{c}\text { Cold } \\
\text { exposure }\end{array}$ & [51] & $5^{\circ} \mathrm{C}$ & 4 weeks & Rats & NA & NA & NA & $\begin{array}{l}\uparrow \text { Mitochondrial enzyme } \\
\text { activity: cytochrome c; } \\
\text { palmitoyl-CoA oxidase; } \\
\text { catalase; acid } \\
\text { phosphatase and } \\
\text { peroxisomal activity }\end{array}$ \\
\hline $\begin{array}{c}\text { Cold } \\
\text { exposure }\end{array}$ & [52] & $-5^{\circ} \mathrm{C}$ & 2 h/day 4 weeks & Rats & $\begin{array}{l}\text { NE-induced } \\
\text { thermogenesis }\end{array}$ & NA & $\begin{array}{c}\uparrow \text { BAT weight and lipid } \\
\text { content }\end{array}$ & NA \\
\hline $\begin{array}{c}\text { Cold } \\
\text { exposure }\end{array}$ & [53] & $-15^{\circ} \mathrm{C}$ & $\begin{array}{c}2 \mathrm{~h} / \text { day for } 10 \\
\text { weeks }\end{array}$ & Rats & & NA & $\uparrow$ BAT weight & NA \\
\hline $\begin{array}{c}\text { Cold } \\
\text { exposure }\end{array}$ & [41] & $5{ }^{\circ} \mathrm{C}$ & $48 \mathrm{~h}$ & Rats & $48 \mathrm{~h}$ fasting & $\begin{array}{c}\uparrow 2 \text {-[3H]deoxyglucose } \\
\text { uptake }\end{array}$ & NA & NA \\
\hline $\begin{array}{c}\text { Cold } \\
\text { exposure }\end{array}$ & [42] & $4{ }^{\circ} \mathrm{C}$ & $\begin{array}{c}\text { Acute: } 4 \mathrm{~h} \\
\text { Chronic: } 1-10 \text { days }\end{array}$ & Female Rats & $24 \mathrm{~h}$ fasting & $\begin{array}{c}\text { Acute: } \\
\uparrow \text { 2-deoxyglucose uptake } \\
\text { Chronic: } \\
\uparrow 2 \text {-deoxyglucose uptake } \\
\uparrow \text { GLUT4 expression } \\
\end{array}$ & NA & NA \\
\hline $\begin{array}{l}\text { Cold } \\
\text { exposure }\end{array}$ & [54] & $4{ }^{\circ} \mathrm{C}$ & 1 to $48 \mathrm{~h}$ & Mice & NA & $\begin{array}{c}\uparrow \text { Gene expression: PDH; } \\
\text { PFK-C; PFK-1; GLUT4; } \\
\text { LDH } \\
\downarrow \text { Gene expression: } \\
\text { GLUT1; GLUT2; GLUT3 } \\
\uparrow 2 \text {-Deoxyglucose uptake }\end{array}$ & $\begin{array}{c}\uparrow \text { Gene expression: } \\
\text { ATP-citrate lyase; FAS; } \\
\text { GPAT; ACC1; ACC2; } \\
\text { LPL; MG lipase; LCAD; } \\
\text { MCAD } \\
\uparrow \text { LCFA } \\
\text { carboxyl-carbon into } \\
\text { BAT (FA uptake) } \\
\uparrow \text { LCFA carboxyl in the } \\
\text { acid-soluble products } \\
\text { (FA utilization) }\end{array}$ & NA \\
\hline $\begin{array}{l}\text { Cold } \\
\text { exposure }\end{array}$ & [55] & $4{ }^{\circ} \mathrm{C}$ & 10 days & Rats & NA & NA & $\begin{array}{c}\uparrow \text { Glyceroneogenesis } \\
\uparrow \text { Glucose incorporation } \\
\text { to glycerol } \\
\uparrow \text { LPL activity }\end{array}$ & NA \\
\hline $\begin{array}{l}\text { Cold } \\
\text { exposure }\end{array}$ & [40] & $4^{\circ} \mathrm{C}$ & $4 \mathrm{~h}$ & Female Rats & NA & $\begin{array}{c}\uparrow{ }^{18} \text { F- or (3)H-FDG } \\
\text { uptake } \\
\uparrow \text { GLUT1 } \\
\text { imunohistolocalization }\end{array}$ & $\downarrow$ Lipid droplet size & $\begin{array}{c}\uparrow \text { UCP1 } \\
\text { immunohistolocalization }\end{array}$ \\
\hline
\end{tabular}


Table 1. Cont.

\begin{tabular}{|c|c|c|c|c|c|c|c|c|}
\hline $\begin{array}{l}\text { Therapeutic } \\
\text { Strategy }\end{array}$ & Reference & Treatment & Duration & $\begin{array}{c}\text { Animal } \\
\text { Model }\end{array}$ & $\begin{array}{l}\text { Experimental } \\
\text { Challenge }\end{array}$ & $\begin{array}{l}\text { BAT Glucose } \\
\text { Metabolism }\end{array}$ & $\begin{array}{l}\text { BAT Lipid } \\
\text { Metabolism }\end{array}$ & $\begin{array}{l}\text { BAT Mitochondrial } \\
\text { Activity }\end{array}$ \\
\hline $\begin{array}{c}\text { Cold } \\
\text { exposure }\end{array}$ & [56] & $4^{\circ} \mathrm{C}$ & 5 weeks & Mice & NA & NA & $\downarrow$ Adipocyte size & $\begin{array}{l}\uparrow \text { Mitochondria number } \\
\uparrow \text { COX4 expression. }\end{array}$ \\
\hline $\begin{array}{c}\text { Cold } \\
\text { exposure }\end{array}$ & [19] & $4{ }^{\circ} \mathrm{C}$ & $24 \mathrm{~h}$ & Mice & NA & $\begin{array}{c}\uparrow^{14} \text { C-desoxyglucose } \\
\text { uptake } \\
\uparrow \text { Gene expression: } \\
\text { GLUT1 and GLUT4 } \\
\uparrow \text { Protein expression: } \\
\text { P-S6 (down-stream target } \\
\text { of the } \\
\text { insulin-AKT-signaling } \\
\text { cascade) }\end{array}$ & $\begin{array}{c}\uparrow \text { BAT uptake of TRL } \\
\uparrow \text { LPL activity } \\
\uparrow \text { CD36 expression }\end{array}$ & NA \\
\hline $\begin{array}{c}\text { Cold } \\
\text { exposure }\end{array}$ & [57] & $4{ }^{\circ} \mathrm{C}$ & Acute and 3 weeks & $\begin{array}{l}\mathrm{UCP} 1-\mathrm{rtTA} \\
\text { mice }\end{array}$ & $\begin{array}{l}\text { Overexpression } \\
\text { of VEGF-A }\end{array}$ & NA & NA & $\begin{array}{c}\uparrow \text { Mitochondrial } \\
\uparrow \text { Oxygen consumption } \\
\text { rate }\end{array}$ \\
\hline $\begin{array}{c}\text { Cold } \\
\text { exposure }\end{array}$ & [58] & $4^{\circ} \mathrm{C}$ & 7,14 , and 21 days & Mice & NA & NA & $\downarrow$ Lipid droplet size & NA \\
\hline $\begin{array}{c}\text { Cold } \\
\text { exposure }\end{array}$ & [59] & $4^{\circ} \mathrm{C}$ & $\begin{array}{c}4 \mathrm{~h}, 24 \mathrm{~h}, 48 \mathrm{~h} \text {, and } \\
72 \mathrm{~h}\end{array}$ & Mice & NA & NA & $\begin{array}{c}\uparrow \text { Protein expression: } \\
\text { PLIN1; PLIN2/ADRP; } \\
\text { ATGL; HSL; pHSL } \\
\uparrow \text { Gene expression: } \\
\text { ADRP }\end{array}$ & $\begin{array}{c}\text { 个 Protein expression: } \\
\text { UCP1; CIDEA } \\
\uparrow \text { Gene expression: UCP1; } \\
\text { PGC1 } \alpha \\
\uparrow \text { Mitochondrial cristae } \\
\text { biogenesis }\end{array}$ \\
\hline $\begin{array}{c}\text { Cold } \\
\text { exposure }\end{array}$ & [60] & $4^{\circ} \mathrm{C}$ & 0.5 to 10 days & AXB8 mice & NA & NA & NA & $\begin{array}{c}\uparrow \text { Protein expression: } \\
\text { UCP1; COXIV; CYTC } \\
\uparrow \text { Gene expression: UCP1 }\end{array}$ \\
\hline $\begin{array}{c}\text { Cold } \\
\text { exposure }\end{array}$ & [61] & $4^{\circ} \mathrm{C}$ & 3 days & Mice & NA & NA & $\begin{array}{l}\uparrow \text { Gene expression: LPL; } \\
\text { LDLrap1; LRP5; Elovl3 } \\
\uparrow \text { Cholesteryl Esters }\end{array}$ & NA \\
\hline $\begin{array}{c}\text { Cold } \\
\text { exposure }\end{array}$ & [62] & $4{ }^{\circ} \mathrm{C}$ & 1 to 7 days & Mice & NA & $\begin{array}{l}\text { } \text { GLUT1 gene expression } \\
\text { (only days } 1 \text { and } 2 \text { ) }\end{array}$ & $\begin{array}{c}\text { Protein expression: } \\
\text { PPAR } \gamma ; \text { aP2 } \\
\uparrow \text { Gene expression: } \\
\text { Elovl3 } \\
\downarrow \text { Lipid droplet size }\end{array}$ & $\begin{array}{c}\uparrow \text { Protein expression: } \\
\text { UCP1 } \\
\uparrow \text { Gene expression: } \\
\text { PGC1 } \alpha \text {; UCP1 }\end{array}$ \\
\hline $\begin{array}{c}\text { Cold } \\
\text { exposure }\end{array}$ & [63] & $4^{\circ} \mathrm{C}$ & $24 \mathrm{~h}, 48 \mathrm{~h}, 96 \mathrm{~h}$ & $\begin{array}{l}\text { Them1-/- } \\
\text { and } \\
\text { Them1+/+ } \\
\text { mice }\end{array}$ & NA & NA & $\downarrow$ Triglyceride content & $\begin{array}{c}\uparrow \text { UCP1 Protein } \\
\text { expression }(96 \mathrm{~h}) \\
\uparrow \text { Oxygen Consumption } \\
\text { Rate }\end{array}$ \\
\hline
\end{tabular}


Table 1. Cont

\begin{tabular}{|c|c|c|c|c|c|c|c|c|}
\hline $\begin{array}{c}\text { Therapeutic } \\
\text { Strategy }\end{array}$ & Reference & Treatment & Duration & $\begin{array}{c}\text { Animal } \\
\text { Model }\end{array}$ & $\begin{array}{l}\text { Experimental } \\
\text { Challenge }\end{array}$ & $\begin{array}{l}\text { BAT Glucose } \\
\text { Metabolism }\end{array}$ & $\begin{array}{l}\text { BAT Lipid } \\
\text { Metabolism }\end{array}$ & $\begin{array}{l}\text { BAT Mitochondrial } \\
\text { Activity }\end{array}$ \\
\hline $\begin{array}{c}\text { Cold } \\
\text { exposure }\end{array}$ & [64] & $16^{\circ} \mathrm{C}$ and $4{ }^{\circ} \mathrm{C}$ & $\begin{array}{c}16^{\circ} \mathrm{C} \text { for } 2 \text { weeks } \\
\text { and } 4^{\circ} \mathrm{C} \text { for more } \\
\text { than } 2 \text { weeks }\end{array}$ & $\begin{array}{c}\text { WT, } \\
\mathrm{UCP} 1-/-, \\
\text { and } \\
\text { SLN-/- } \\
\text { mice }\end{array}$ & NA & NA & $\begin{array}{l}\downarrow \text { Lipid droplet size } \\
\text { (WT and SLN-/-) }\end{array}$ & $\begin{array}{c}\uparrow \mathrm{UCP} 1 \\
\text { imunohistolocalization } \\
\uparrow \text { protein expression: } \\
\text { UCP1; TFAM, complex1 } \\
\text { and } 2 \\
\uparrow \text { Mitochondria cristae } \\
\text { (results found in WT and } \\
\text { SLN-/-) }\end{array}$ \\
\hline $\begin{array}{c}\text { Cold } \\
\text { exposure }\end{array}$ & [65] & $5^{\circ} \mathrm{C}$ & 7 days & Mice & NA & NA & $\begin{array}{c}\text { Remodeling of } \\
\text { glycerophospholipids }\end{array}$ & $\uparrow$ Cardiolipins \\
\hline $\begin{array}{c}\text { Cold } \\
\text { exposure }\end{array}$ & [66] & $5{ }^{\circ} \mathrm{C}$ & $\begin{array}{c}3 \text { h, } 3 \text { days, or } 3 \\
\text { weeks }\end{array}$ & Mice & NA & $\begin{array}{l}\uparrow \text { Glucose metabolism } \\
\text { signaling pathway }\end{array}$ & $\begin{array}{c}\uparrow \text { Signaling pathways: } \\
\text { phospholipids } \\
\text { metabolism; TAG } \\
\text { biosynthesis; } \\
\text { Glycerophospholipid } \\
\text { biosynthesis; Fatty } \\
\text { Acyl-CoA biosynthesis. }\end{array}$ & $\begin{array}{c}\uparrow \text { CRLS1 expression } \\
\uparrow \text { Cardiolipins } \\
\uparrow \text { TCA pathway } \\
\uparrow \text { ETC pathway }\end{array}$ \\
\hline Exercise & [52] & $\begin{array}{l}\text { Treadmill } \\
\text { training } \\
(25 \mathrm{~m} / \mathrm{min})\end{array}$ & 4 weeks & Rats & $\begin{array}{l}\text { Warm }\left(24{ }^{\circ} \mathrm{C}\right) \\
\text { and cold } \\
\text { acclimation }(-5 \\
{ }^{\circ} \mathrm{C}, 2 \mathrm{~h} / \text { day); } \\
\text { All groups: } \\
\text { NE-induced } \\
\text { thermogenesis }\end{array}$ & NA & $\begin{array}{l}\downarrow \text { Lipid content in } \\
\text { warm acclimated } \\
\text { trained compared to } \\
\text { warm-acclimated } \\
\text { sedentary. } \\
\text { No differences in lipid } \\
\text { content in } \\
\text { cold-acclimated } \\
\text { sedentary versus } \\
\text { trained. }\end{array}$ & NA \\
\hline Exercise & [67] & $\begin{array}{l}\text { Treadmill } \\
\text { training }\end{array}$ & $\begin{array}{l}90 \mathrm{~min} / \text { day } \\
6 \text { weeks }\end{array}$ & Male rats & NE stimulation & NA & NA & $\begin{array}{l}\downarrow \text { BAT Blood flow (but } \\
\text { blood flow does not } \\
\text { change between groups } \\
\text { under NE stimulation) }\end{array}$ \\
\hline Exercise & [53] & Swimming & $\begin{array}{c}2 \mathrm{~h} / \text { day for } 10 \\
\text { weeks }\end{array}$ & Rats & NA & NA & $\downarrow$ BAT weight & NA \\
\hline Exercise & [31] & $\begin{array}{l}\text { Treadmill } \\
\text { training } \\
(23 \mathrm{~m} / \mathrm{min})\end{array}$ & 6 weeks & $\begin{array}{l}\text { Ovariectomized } \\
\text { rats }\end{array}$ & NA & NA & NA & $\begin{array}{c}\uparrow \text { Mitochondrial protein } \\
\text { content } \\
\uparrow \text { Cytochrome oxidase } \\
\text { activity } \\
\uparrow \text { Oxygen consumption }\end{array}$ \\
\hline
\end{tabular}


Table 1. Cont.

\begin{tabular}{|c|c|c|c|c|c|c|c|c|}
\hline $\begin{array}{l}\text { Therapeutic } \\
\text { Strategy }\end{array}$ & Reference & Treatment & Duration & $\begin{array}{c}\text { Animal } \\
\text { Model }\end{array}$ & $\begin{array}{c}\text { Experimental } \\
\text { Challenge }\end{array}$ & $\begin{array}{l}\text { BAT Glucose } \\
\text { Metabolism }\end{array}$ & $\begin{array}{l}\text { BAT Lipid } \\
\text { Metabolism }\end{array}$ & $\begin{array}{l}\text { BAT Mitochondrial } \\
\text { Activity }\end{array}$ \\
\hline Exercise & {$[68]$} & Swimming & 6 weeks & $\begin{array}{l}\text { Male young } \\
\text { and old mice }\end{array}$ & NA & NA & $\uparrow$ BAT weight & $\begin{array}{c}\uparrow \text { Mitochondrial protein } \\
\text { content } \\
\uparrow \text { UCP1 antigen level } \\
\uparrow \text { GDP binding (indicator } \\
\text { of UCP1 activity) }\end{array}$ \\
\hline Exercise & [34] & Swimming & 21 days & Rats & $\begin{array}{c}\text { TSH-stimulation } \\
\text { test } \\
\text { in cold }\left(4{ }^{\circ} \mathrm{C}\right) \\
\text { for } 30 \text { min or no } \\
\text { TST in } 30{ }^{\circ} \mathrm{C} \text { for } \\
30 \mathrm{~min}\end{array}$ & NA & NA & $\downarrow 5^{\prime}$ deiodinating activity \\
\hline Exercise & [30] & $\begin{array}{l}\text { Treadmill } \\
\text { training }(15 \\
\mathrm{m} / \mathrm{min})\end{array}$ & 8 weeks & $\begin{array}{l}\text { Chow diet } \\
\text { mice and } \\
\text { HFD mice }\end{array}$ & NA & NA & NA & $\begin{array}{c}\uparrow \mathrm{UCP} 1 \text { and Dio2 } \\
\text { expression }\end{array}$ \\
\hline Exercise & [69] & Swimming & 8 weeks & $\begin{array}{l}\text { Ovariectomized } \\
\text { rats }\end{array}$ & NA & NA & NA & $\begin{array}{l}\uparrow \text { Mitochondrial oxygen } \\
\text { consumption }\end{array}$ \\
\hline Exercise & [38] & $\begin{array}{l}\text { Endurance } \\
(\approx 60 \% \text { of } \\
\left.\mathrm{VO}_{2} \max \right), 5 \\
\text { days/week }\end{array}$ & 1 and 6 weeks. & $\begin{array}{c}\text { Male } \\
\text { Sprague } \\
\text { Dawley rats }\end{array}$ & $\begin{array}{l}\text { With or without } \\
\text { recovery }\end{array}$ & $\begin{array}{c}\text { No change in GLUT1 and } \\
4 \text { expression }\end{array}$ & $\begin{array}{c}\uparrow \text { Unilocular lipid } \\
\text { droplet }\end{array}$ & $\begin{array}{c}\uparrow \text { PGC- } 1 \alpha \text { and PGC- } 1 \beta \\
\text { expression and weak } \\
\text { UCP1 } \\
\uparrow \text { parenchymal } \\
\text { vascularization } \\
\uparrow \text { MCT- } 1 \text { lactate } \\
\text { transporter }\end{array}$ \\
\hline Exercise & [32] & $\begin{array}{c}\text { Treadmill } \\
\text { training } \\
(70-85 \% \\
\mathrm{VO}_{2} \mathrm{max}\end{array}$ & 8 weeks & Rats & NA & NA & $\uparrow$ Lipid droplet area. & $\begin{array}{l}\downarrow \text { Protein expression: } \\
\quad \text { UCP1; PGC1 } \alpha \\
\downarrow \text { Palmitate oxidation. }\end{array}$ \\
\hline Exercise & [70] & $\begin{array}{c}\text { Progressive } \\
\text { treadmill } \\
\text { training } \\
(18-25 \mathrm{~m} / \mathrm{min} \\
\text { for } 30-60 \mathrm{~min} \\
\text { at } 10 \% \text { incline })\end{array}$ & 8 weeks & Male rats & NA & NA & $\begin{array}{c}\uparrow \text { Storage protein } \\
\text { PLIN5 } \\
\text { No change in synthesis } \\
\text { FAS } \\
\text { but } \downarrow \text { in ACC } \\
\downarrow \text { pHSL } / \text { HSL protein } \\
\text { expression }\end{array}$ & $\begin{array}{c}\text { No changes in } \\
\text { mitochondrial proteins } \\
\text { COX IV, PDH, UCP1 }\end{array}$ \\
\hline Exercise & [71] & $\begin{array}{l}\text { Wheel cage } \\
\text { running }\end{array}$ & 3 weeks & Male mice & NA & NA & $\begin{array}{c}\downarrow \text { Fatty acid } \\
\text { biosynthesis gene } \\
\text { expression: Acaca; } \\
\text { Scd1; Agpat3; Dgkd; } \\
\text { Mlxipl } \\
\downarrow \text { Overall abundance of } \\
\text { TAG }\end{array}$ & NA \\
\hline
\end{tabular}


Table 1. Cont

\begin{tabular}{|c|c|c|c|c|c|c|c|c|}
\hline $\begin{array}{l}\text { Therapeutic } \\
\text { Strategy }\end{array}$ & Reference & Treatment & Duration & $\begin{array}{c}\text { Animal } \\
\text { Model }\end{array}$ & $\begin{array}{c}\text { Experimental } \\
\text { Challenge }\end{array}$ & $\begin{array}{l}\text { BAT Glucose } \\
\text { Metabolism }\end{array}$ & $\begin{array}{c}\text { BAT Lipid } \\
\text { Metabolism }\end{array}$ & $\begin{array}{l}\text { BAT Mitochondrial } \\
\text { Activity }\end{array}$ \\
\hline Exercise & [29] & $\begin{array}{c}\text { Treadmill } \\
\text { training, } \\
55-65 \% \text { of } \\
\text { maximal } \\
\text { running speed } \\
(15-20 \\
\mathrm{m} / \mathrm{min})\end{array}$ & 8 weeks & Rats & NA & $\begin{array}{l}\uparrow \text { Insulin signaling } \\
\text { protein expression: IR; } \\
\text { p-IRS-1; pERK }\end{array}$ & NA & $\begin{array}{c}\uparrow \text { Protein expression: } \\
\text { NRF1; TFAM; PGC1 } \alpha \text {; } \\
\text { SIRT1; pAMPK/AMPK } \\
\text { ratio; ATP synthase; } \\
\text { mMDH; UCP1; UCP2; } \\
\text { UCP3 }\end{array}$ \\
\hline Exercise & [72] & $\begin{array}{l}\text { Swimming in } \\
\text { low and } \\
\text { moderate } \\
\text { intensities }\end{array}$ & 13 weeks & $\begin{array}{c}\text { Metabolic } \\
\text { syndrome, } \\
\text { high fat fed } \\
\left(\begin{array}{c}30 \% \text { lard }) \\
\text { rats }\end{array}\right.\end{array}$ & NA & $\begin{array}{c}\uparrow \text { Akt-2 and GLUT4 gene } \\
\text { expression }\end{array}$ & NA & NA \\
\hline Exercise & [73] & $\begin{array}{l}\text { Wheel cage } \\
\text { running }\end{array}$ & 3 weeks & Mice & NA & $\begin{array}{l}\uparrow \text { Gene expression: } \\
\text { GLUT4; Hk2; Eno1 } \\
\downarrow \text { Glucose uptake }\end{array}$ & $\begin{array}{c}\uparrow \text { Gene expression: } \\
\text { Fabp3; Acsl3; Gpd1; } \\
\text { Gyk } \\
\downarrow \text { pHSL/HSL protein } \\
\text { expression }\end{array}$ & $\begin{array}{c}\uparrow \text { Gene expression: Cidea; } \\
\text { Cd36; Citrate synthase; } \\
\text { UCP1 } \\
\downarrow \text { NADH fluorescence } \\
\text { intensity } \\
\downarrow \text { Oxygen consumption } \\
\text { rate }\end{array}$ \\
\hline
\end{tabular}

NA: Not available; PDH: Pyruvate dehydrogenase; PFK: Phosphofructokinase; LDH: Lactate dehydrogenase; FAS: Fatty Acid Synthase; GPAT: Glycerol-3-Phosphate Acyltransferase; ACC: Acetyl-CoA carboxylase; LPL: lipoprotein lipase; UCP1: mitochondrial uncoupling protein 1; MG: monoacylglycerol; LACD: Long-chain acyl-CoA dehydrogenase; MCAD: medium-chain acyl-CoA dehydrogenase; LCFA: Long-chain Fatty Acids; COX: Cytochrome c oxidase; AKT: RAC-alpha serine/threonine-protein kinase (PKB); CD36: cluster of differentiation 36; VEGF: Vascular endothelial growth factor; PLIN: Perilipin; ADRP: Adipose differentiation-related protein; ATGL: Adipose triglyceride lipase; HSL: Hormone-sensitive lipase; CIDEA: Cide domain-containing protein Cidea; PGC1 $\alpha$ : Peroxisome proliferator-activated receptor gamma coactivator 1-alpha; CYTC: Cytochrome C; LDL: low-density lipoproteins; LRP: Lipoprotein receptor-related protein; ELOVL: Elongation of very long chain fatty acids protein; PPAR $\gamma$ : peroxisome proliferator-activated receptors gamma; WT: Wild Type; SLN: Sarcolipin; TFAM: Mitochondrial transcription factor A; CRLS: Cardiolipin Synthase; TCA: tricarboxylic acid cycle; ETC: electron transport chain; GDP: guanine diphosphate; TSH: Thyroid-stimulating hormone; HFD: High Fat Diet; Dio2: Type II iodothyronine deiodinase; MCT-1: Proton-linked monocarboxylate transporter, member 1; Acaca: Acetyl-CoA Carboxylase Alpha; Scd1: stearoyl-CoA desaturase 1; AGPAT: Acyl-CoA:glycerol-3-phosphate acyltransferase; Dgkd: Diacylglycerol kinase delta; Mlxipl: MLX-interacting protein-like; IR: Insulin Receptor; IRS: Insulin Receptor Substrate; ERK: extracellular signal-regulated kinase; NRF: Nuclear respiratory factor; SIRT1: Sirtuin 1; mMDH: Mitochondrial malate dehydrogenase; Hk2: Hexokinase 2; Eno1: Enolase 1; Fabp3: fatty acid-binding protein 3; Acsl3: Long-chain-fatty-acid-CoA ligase 3; Gpd1: Glycerol-3-phosphate dehydrogenase; Gyk: glycerokinase; NADH: Reduced Nicotinamide adenine dinucleotide. 
Table 2. Effect of cold and exercise on BAT metabolism in humans.

\begin{tabular}{|c|c|c|c|c|c|c|c|c|}
\hline $\begin{array}{l}\text { Therapeutic } \\
\text { Strategy }\end{array}$ & Reference & Treatment & Duration & Study Subjects & $\begin{array}{l}\text { Experimental } \\
\text { Challenge }\end{array}$ & $\begin{array}{l}\text { Effects on } \\
\text { Glucose } \\
\text { Metabolism }\end{array}$ & $\begin{array}{l}\text { Effects on Lipid } \\
\text { Metabolism }\end{array}$ & $\begin{array}{c}\text { Effects on BAT } \\
\text { Mitochondrial Activity }\end{array}$ \\
\hline $\begin{array}{c}\text { Cold } \\
\text { exposure }\end{array}$ & [74] & $\begin{array}{l}\text { Cold outdoor weather } \\
\text { in Northern Finland }\end{array}$ & NA & $\begin{array}{c}\text { Male and } \\
\text { female outdoor } \\
\text { workers }\end{array}$ & NA & NA & NA & $\begin{array}{c}\uparrow \text { Enzyme activity: } \\
\beta \text {-hydroxybutyrate } \\
\text { dehydrogenase; } \\
\text { Succinate dehydrogenase; } \\
\text { Monoamine oxidase }\end{array}$ \\
\hline $\begin{array}{c}\text { Cold } \\
\text { exposure }\end{array}$ & [46] & $16^{\circ} \mathrm{C}$ & $2 \mathrm{~h}$ & Male & NA & $\begin{array}{c}\uparrow^{18} \text { F-FDG } \\
\text { uptake }\end{array}$ & NA & NA \\
\hline $\begin{array}{c}\text { Cold } \\
\text { exposure }\end{array}$ & [45] & $17^{\circ} \mathrm{C}$ & $2 \mathrm{~h}$ & Male and female & $\begin{array}{l}\text { Foot in cold } \\
\text { water }(5 \mathrm{~min} \\
\text { in } / 5 \text { min out } \\
\text { PET/CT session }\end{array}$ & $\begin{array}{l}\uparrow{ }^{18} \text { F-FDG } \\
\text { uptake }\end{array}$ & NA & NA \\
\hline $\begin{array}{c}\text { Cold } \\
\text { exposure }\end{array}$ & [44] & $\begin{array}{l}19{ }^{\circ} \mathrm{C} \text { room and feet on } \\
\text { an ice block } \\
\text { intermittently ( } 4 \text { min } \\
\text { every } 5 \text { min) }\end{array}$ & $1 \mathrm{~h}$ & Male and female & NA & $\begin{array}{c}{ }^{18} \text { F-FDG } \\
\text { uptake }\end{array}$ & NA & NA \\
\hline $\begin{array}{c}\text { Cold } \\
\text { exposure }\end{array}$ & [75] & $\begin{array}{c}19^{\circ} \mathrm{C} \text { and were } \\
\text { decreased by } 1^{\circ} \mathrm{C} \\
\text { approximately every } 30 \\
\text { min until shivering. }\end{array}$ & $5-8 h$ & Male & NA & $\begin{array}{l}\uparrow{ }^{18} \text { F-FDG } \\
\text { uptake }\end{array}$ & NA & $\begin{array}{c}\uparrow U C P 1 \\
\text { imunohistolocalization; } \\
\uparrow \text { Uncoupled } \\
\text { Mitochondrial respiration }\end{array}$ \\
\hline $\begin{array}{c}\text { Cold } \\
\text { exposure }\end{array}$ & [48] & $14^{\circ} \mathrm{C}-15^{\circ} \mathrm{C}$ & 10 days & $\begin{array}{c}\text { Male T2DM } \\
\text { subjects }\end{array}$ & NA & $\begin{array}{l}{ }^{\uparrow}{ }^{18} \text { F-FDG } \\
\text { uptake }\end{array}$ & NA & NA \\
\hline $\begin{array}{c}\text { Cold } \\
\text { exposure }\end{array}$ & [76] & $18^{\circ} \mathrm{C}$ & $2 \mathrm{~h}$ & Male T2DM & NA & NA & $\uparrow^{18}$ FTHA uptake & NA \\
\hline $\begin{array}{c}\text { Cold } \\
\text { exposure }\end{array}$ & [47] & $\begin{array}{c}19^{\circ} \mathrm{C} \text { and were } \\
\text { decreased by } 1{ }^{\circ} \mathrm{C} \\
\text { approximately every } 30 \\
\text { min until subjects } \\
\text { reported shivering }\end{array}$ & $6 \mathrm{~h}$ & Male & NA & $\begin{array}{l}\uparrow{ }^{18} \text { F-FDG } \\
\text { uptake }\end{array}$ & NA & NA \\
\hline $\begin{array}{c}\text { Cold } \\
\text { exposure }\end{array}$ & [50] & $18^{\circ} \mathrm{C}$ & $5-8 \mathrm{~h}$ & Male obese & NA & $\begin{array}{l}\uparrow{ }^{18} \text { F-FDG } \\
\text { uptake }\end{array}$ & $\begin{array}{l}\uparrow \text { LPL, CD36 gene } \\
\text { expression. } \\
\text { Association between } \\
\text { BAT volume and FFA } \\
\text { uptake and oxidation }\end{array}$ & $\begin{array}{c}\uparrow \mathrm{UCP} 1 \text { gene expression } \\
\uparrow \text { Oxygen consumption } \\
\text { rate }\end{array}$ \\
\hline $\begin{array}{c}\text { Cold } \\
\text { exposure }\end{array}$ & [77] & $18^{\circ} \mathrm{C}$ & $\begin{array}{l}5 \mathrm{~h} \text { and } 4 \\
\text { weeks }\end{array}$ & Male & NA & NA & $\begin{array}{l}\uparrow \text { DFA and }{ }^{18} \text { FTHA } \\
\text { uptake in acute } \\
\text { stimulation; no } \\
\text { further increase after } \\
\text { chronic stimulation } \\
\end{array}$ & NA \\
\hline
\end{tabular}


Table 2. Cont.

\begin{tabular}{|c|c|c|c|c|c|c|c|c|}
\hline $\begin{array}{l}\text { Therapeutic } \\
\text { Strategy }\end{array}$ & Reference & Treatment & Duration & Study Subjects & $\begin{array}{l}\text { Experimental } \\
\text { Challenge }\end{array}$ & $\begin{array}{c}\text { Effects on } \\
\text { Glucose } \\
\text { Metabolism }\end{array}$ & $\begin{array}{l}\text { Effects on Lipid } \\
\text { Metabolism }\end{array}$ & $\begin{array}{c}\text { Effects on BAT } \\
\text { Mitochondrial Activity }\end{array}$ \\
\hline Exercise & [33] & $\begin{array}{c}\text { Endurance-trained } \\
\text { athletes }\end{array}$ & NA & Males & $\begin{array}{l}2 \mathrm{~h} \text { cold } \\
\text { exposure }\end{array}$ & $\begin{array}{l}\downarrow\left[{ }^{18} \mathrm{~F}\right] \mathrm{FDG} \\
\text { uptake }\end{array}$ & NA & NA \\
\hline Exercise & [78] & $\begin{array}{l}\text { Athletes versus } \\
\text { non-athletes }\end{array}$ & NA & Female & $\begin{array}{c}14^{\circ} \mathrm{C} \text { for } 120 \\
\min \end{array}$ & $\begin{array}{c}\text { Trend to } \downarrow \\
{\left[{ }^{18} \text { F]FDG }\right.} \\
\text { uptake }\end{array}$ & NA & NA \\
\hline Exercise & [79] & $\begin{array}{l}\text { HIIT and moderate } \\
\text { continuous training }\end{array}$ & 2 weeks & $\begin{array}{c}\text { Healthy } \\
\text { middle-aged } \\
\text { men }\end{array}$ & $\begin{array}{c}\text { Insulin } \\
\text { stimulated } \\
\text { glucose uptake }\end{array}$ & $\begin{array}{l}\text { No changes in } \\
\text { glucose uptake }\end{array}$ & NA & NA \\
\hline
\end{tabular}

NA: Not available; LPL: lipoprotein lipase; MG: monoacylglycerol; CD36: cluster of differentiation 36; UCP1: mitochondrial uncoupling protein 1; 18FTHA: 14(R,

S)-[(18)F]Fluoro-6-thia-heptadecanoic acid; DFA: dietary fatty acids; HIIT: High-intensity interval training. 


\subsection{Exercise Has Conflicting Effects in Glucose Metabolism in BAT}

Exercise is an effective therapy to improve glucose metabolism and insulin sensitivity in skeletal muscle [80,81], heart [82], and WAT [28,83]. Since BAT plays an important role in regulating glucose metabolism, several studies have investigated how exercise can affect glucose uptake in BAT $[29,33,72,73,79]$ (Table 1$)$.

Some rodent studies have shown that exercise (treadmill training or swimming) $[29,72]$ increases the expression of proteins related to insulin signaling in BAT. This would indicate an increase in glucose uptake into BAT, but that was not directly measured in these studies. In contrast, separate studies have determined that GLUT1 and 4 are not changed in BAT in response to exercise $[38,73]$. These differences in outcomes for exercise and BAT activity might be due in part to the intrinsic differences in exercise modalities, duration, experimental challenges, rodent model or strain used, and measurement of BAT activity. Additionally, a recent study from our laboratory investigated the effects of 3 weeks of wheel-cage running on glucose metabolism in mice. Exercise increased the expression of genes involved in glucose metabolism in BAT, but brown adipocytes differentiated from the stromal vascular fraction (SVF) isolated from exercise-trained BAT had decreased basal glucose uptake compared to brown adipocytes differentiated from sedentary BAT [73] (Table 1). It is important to note that in vitro conditions seldom include sympathetic innervation and lack neural innervation and vascular supply, the absence of which could impact BAT function. Our results show that mature brown adipocytes from exercise-trained BAT, in the absence of innervation, have reduced glucose uptake.

In humans, recent studies have investigated the effects of exercise on glucose uptake in BAT. One study used ${ }^{18}$ FDG-PET-CT to examine the effects of short-term, high-intensity interval training and moderate-intensity continuous training in sedentary, healthy, male subjects. Interestingly, exercise training decreased insulin-stimulated glucose uptake in BAT [79] (Table 2). Other studies examined the effects of endurance exercise on BAT glucose uptake. Self-reported endurance athletes had a decrease in cold-stimulated glucose uptake in BAT compared to sedentary male [33] and female subjects [78] after $2 \mathrm{~h}$ of cold exposure. These data suggest that in humans, exercise decreases glucose uptake in BAT. The mechanism for this is unclear; while ${ }^{18}$ FDG PET-CT is still considered an important method to identify BAT volume and activity, it is possible the primary role of exercise on BAT is not to stimulate glucose uptake into BAT. It is also probable that exercise-trained subjects have a greater lean mass compared to sedentary subjects and have increased ${ }^{18} \mathrm{FDG}$ uptake into their skeletal muscle, causing an underestimation of BAT activity [84]. The effects of exercise on glucose metabolism in BAT have also not been investigated in obese subjects. Thus, more studies are necessary to elucidate the effects of exercise on glucose metabolism in BAT in obese and type 2 diabetic subjects.

Cold exposure and exercise have distinct effects on glucose metabolism in BAT. While cold exposure has been clearly shown to increase BAT glucose uptake $[19,22,23]$, several studies indicate that exercise reduces glucose uptake in BAT $[33,73,79]$ (Figure 1). Nevertheless, during exercise the skeletal muscle requires high levels of glucose uptake and glucose metabolism [80] thus to maintain whole-body homeostasis, the body may decrease glucose uptake into BAT in order to provide substrates to the working skeletal muscle $[79,85]$, and this feature may be shared for certain muscles during mild, acute cold exposure [86]. The differences between cold and exercise-stimulated BAT glucose uptake might be partly related to the increased thermogenic activation of BAT during cold, but not exercise. The beneficial effects of exercise on BAT may be independent of BAT glucose metabolism [15].

\section{BAT and Fatty Acid Metabolism}

Free fatty acids (FFA) are the main substrates for BAT thermogenesis [22]. BAT activation stimulates lipolysis of the intracellular triacylglycerols (TAGs) $[22,87]$ and increases uptake of circulating fatty acids and lipoproteins [88] to provide fuel for thermogenesis in rodents $[19,58]$ and humans $[50,77]$. Here, we will discuss the role of cold exposure and exercise on fatty acid metabolism in BAT. 


\subsection{Cold Increases Fatty Acid Uptake and Metabolism in BAT}

Activation of BAT by cold stimulates the lipolysis of intracellular TAG, releasing long-chain fatty acids that activate UCP1 and increase mitochondrial respiration and thermogenesis in rodents $[19,58]$ and humans [47,77] (Table 1). Cold exposure stimulates the uptake of non-esterified fatty acids (NEFA) from WAT lipolysis and fatty acids from triglyceride-rich lipoproteins (TRL) $[19,88]$ into BAT. Studies in rodents have shown that both acute (1-48 h) [54] and chronic (10 days) [55] cold exposure increase the expression of genes related to FFA synthesis, FFA uptake and oxidation in BAT. These results indicate that cold exposure elicits an increase in FFA uptake and metabolism in BAT.

Studies in humans have shown that activated BAT is correlated to cold-induced lipolysis, increased FFA re-esterification, FFA oxidation, energy expenditure, and insulin sensitivity compared to individuals with no or minimal BAT activity in both lean $[75,76]$ and obese [50] individuals (Table 2). Additionally, upon mild cold exposure, BAT extracts dietary FA at a higher rate than skeletal muscle [77]. This indicates that BAT is important in lipid and fatty acid metabolism, and that activation of BAT by cold stimulates an increase in fatty acid uptake and metabolism. BAT activation by cold exposure may have beneficial effects on obese and type 2 diabetic patients with altered lipid metabolism.

\subsection{Exercise Decreases Lipid Metabolism in BAT}

Exercise uses lipids as an energy source for skeletal muscle [89]. In addition to promoting skeletal muscle FFA uptake and utilization, exercise increases FFA mobilization from WAT. With regard to BAT, early studies compared exercise training and cold exposure in rodents and observed that the activity, weight, and lipid content in BAT increased with cold exposure and decreased with exercise $[52,53]$. Recent studies have provided conflicting evidence regarding the effects of exercise on BAT lipid accumulation and lipolysis (Table 1). One recent study revealed that 3 weeks of wheel-cage exercise in mice increased expression of several genes involved in fatty acid uptake and oxidation in BAT but significantly decreased the pHSL/HSL ratio, indicating a decrease in lipolysis [73], which is consistent with previous reports on the effects of treadmill training on BAT metabolism [70]. Despite the reduction in lipolysis by exercise, the effect on lipid droplet proteins appears to be similar to that of cold-exposed BAT [59] (Table 1). Studies have shown that exercise likely induces lipoprotein remodeling in BAT [70], similar to the remodeling events that occur with cold exposure, and may facilitate increased thermogenesis [59]. Exercise and cold exposure likely prime lipid droplet and FA lipid synthesis, and lipolysis in different ways that are likely to influence thermogenesis and overall activity in BAT. This decrease in lipolysis is the opposite of what occurs during cold exposure. The role of exercise on lipid metabolism in BAT has not been thoroughly investigated; these initial studies indicate that lipid uptake, accumulation, and lipolysis are all increased with cold exposure in rodents and humans, while exercise induces the opposite response (Figure 1).

\section{Thermogenic and Mitochondrial Activity in BAT}

The thermoregulatory and metabolic actions of BAT are dependent on mitochondrial function $[90,91]$. In BAT, mitochondria function to dissipate the proton gradient through UCP1 upon activation, thus generating heat [22]. Increased energy intake, a driving force of obesity, may alter mitochondrial function in BAT [92] resulting in impaired thermogenic function. Here, we will discuss the role of cold exposure and exercise training on the mitochondrial activity of BAT.

\subsection{Cold Exposure Increases Mitochondrial Content and Activity}

Long term cold exposure results in many adaptations in BAT which improve its thermogenic capacity, including increased mitochondrial content and function [22]. Chronic cold exposure in rodents $\left(4{ }^{\circ} \mathrm{C}-16{ }^{\circ} \mathrm{C}\right.$ for 5 to 25 days) increases mitochondrial content, UCP1 expression, and oxidative capacity and respiration $[51,59,60,64]$. Exposure to cold also increases markers of mitochondrial 
biogenesis such as PGC1 $\alpha$, NRF1, TFAM, cytochrome c oxidase (COX), and mtDNA $[17,29,51,56,62]$, and oxygen consumption rate $[57,63]$ (Table 1$)$.

In humans, the mitochondrial enzyme activity in BAT was measured in men who performed work outdoors at very low temperatures compared to workers who performed the same task at ambient temperatures. Outdoor workers had an increase in mitochondrial content and activity of mitochondrial enzymes including $\beta$-hydroxybutyrate dehydrogenase, succinate dehydrogenase, and monoamine oxidase [74] (Table 2). It is important to note, however, that a recent study in healthy men demonstrated that the bulk of cold-induced glucose uptake was mediated by deeper and central muscles of the neck and back, as well as the inner thigh muscles [86], and not the BAT. This emphasizes the coordinated metabolic response of BAT and muscle in response to cold. Together, these findings indicate that cold exposure increases mitochondrial content and activity in BAT in both rodents and humans.

\subsection{Exercise Alters Mitochondrial Content and Activity}

Chronic exercise is related to increased mitochondrial activity, biogenesis, and mitophagy in multiple tissues including the heart, skeletal muscle, and white adipose tissue [82,83,93-95]. Several studies have examined the effects of exercise on BAT thermogenesis and mitochondrial activity in rodents, with mixed results. Some studies indicated that chronic exercise training increased mitochondrial activity [69], energetics (CPTII, mF1 ATP synthase, MDH) [29], UCP1 content [68], mitochondrial respiration $[69,73]$, and upregulated genes involved in mitochondrial biogenesis in BAT including Pgc1a, Tfam, and Nrf1 [29-31]. One study showed that, at the ultrastructural level, exercise increased the number of large mitochondria in BAT compared to cold exposure [38]. The functional implications of the larger mitochondria in BAT, or that mechanisms that led to this morphological change, have not been determined (Table 1). Other studies have indicated that exercise does not affect the thermogenic or mitochondrial activity of BAT [53,67], and a third set of studies showed that exercise decreased the thermogenic and mitochondrial activity of BAT [32-34]. Recent work in our laboratory showed that 3 weeks of voluntary wheel running in mice decreased functional mitochondrial activity. Basal oxygen consumption rates in the stromal vascular fraction (SVF) isolated from trained BAT differentiated into adipocytes were decreased compared SVF isolated from sedentary BAT. Mitochondrial activity (measured by NADH autofluorescence in vivo) was also significantly decreased after 11 days of exercise [73]. While our data shows that exercise decreases BAT mitochondrial activity, it is possible that different exercise modalities, durations, age of animals, and experimental challenges could induce a different response (Table 1).

Together these studies suggest that cold exposure increases mitochondrial content and activity in BAT to generate heat production and increase energy expenditure, while the effects of exercise on the mitochondrial activity of BAT are less clear (Figure 1). While this has been investigated in rodents, to our knowledge, this has not been investigated in humans. More work is needed to fully establish the role of exercise on the mitochondrial activity in BAT.

\section{Cold and Exercise Alter Structural Lipids in BAT}

In addition to providing energy, lipids are important central constituents of cellular and organelle membranes $[96,97]$. The lipidomic profile of BAT is different than that of WAT, likely related to the high density of mitochondria and sympathetic innervation in BAT [98]. Recent studies have investigated the profile of structural lipids in BAT in response to cold and exercise; we will discuss these studies below.

\subsection{Cold Induces Species-Specific Changes in BAT Structural Lipids}

Recent studies have investigated the effects of cold exposure on the lipidomic profile of BAT using RNA-Seq and mass spectrometry (MS) based lipidomics. Three days of cold exposure $\left(4^{\circ} \mathrm{C}\right)$ resulted in selective remodeling of BAT lipid content, with changes in the fatty acyl composition of TAGs and increased cholesteryl esters (CEs) [61]. The expression of genes related to lipoprotein uptake and turnover (Lpl, Ldlrap1, and Lrp5) and elongation of saturated and monounsaturated C18-C22 fatty acid 
substrates (Elovl3) were also elevated, indicating that cold exposure increases the uptake of fatty acids from lipoproteins into BAT, which are subsequently esterified into TAGs. The composition of TAG species in BAT was also altered in response to cold, with a significant increase in odd-numbered, longand very-long-chain saturated fatty acyls as a result of increased long-chain fatty acids metabolism, elongation, and esterification into TAGs.

Three days of cold exposure also induced a selective remodeling of glycerophospholipid species in BAT, with increased 18:0 acyl chains composition in phosphatidylcholine (PC) and phosphatidylethanolamine (PE), 18:0 and 18:1 in lysophosphatidylethanolamines (LPE), and 18:2 in phosphatidylserine (PS). The increase in 18:0 acyl chains leads to increased mitochondrial respiratory capacity after cold exposure [99]. Additionally, genes involved in synthesis and remodeling of glycerophospholipids in BAT were also increased after cold exposure. Glycerophospholipids are important components of cellular and mitochondrial membranes [100] and can act in important signaling pathways related to brown adipocyte proliferation, lipid oxidation, and thermogenesis through the activation of ligand-activated transcription factors. Thus, the cold-mediated changes in glycerophospholipid subspecies may affect signaling cascades and transcription factors in the cold-induced thermogenic adaptation.

Similarly, another study investigated the effects of 7 days of cold exposure $\left(5^{\circ} \mathrm{C}\right)$ on the lipidomic profile of serum and BAT [65] (Table 1). Seven days of cold exposure resulted in selective remodeling of glycerophospholipids in BAT, increasing phosphatidylglycerol (PG) and cardiolipins (CL) species. The increased CL levels were also observed in the serum of humans exposed to $14{ }^{\circ} \mathrm{C}$ for $1 \mathrm{~h}$. PG is a phospholipid precursor for CL [101], and CL constitutes up to $20 \%$ of total mitochondrial membrane lipids. CL binds directly to UCP1 to increase its tethering within the mitochondrial membrane [102]. Another study investigating the effects of chronic cold exposure ( 3 weeks) also determined an increase in PG and CL in BAT [66], and an increase in the enzyme CL synthase 1 (CRLS1), which was correlated with the increases in UCP1 expression, uncoupled respiration, glucose uptake, and systemic insulin sensitivity. Since CL production is reduced in BAT in obese mice [103] and alterations in CL have been associated with mitochondrial dysfunction in several pathological conditions and diseases including obesity and T2DM [103-105], a cold-induced increase in CLs in BAT supports a potential mechanism through which cold exposure could help control systemic glucose regulation. Taken together, these studies show that changes in structural lipid metabolism by cold exposure can exert an important function on BAT thermogenesis and improve metabolic health, and these adaptations to structural lipids are observed as early as 3 days after cold exposure.

\subsection{Exercise Induced Changes to BAT Structural Lipids Are the Opposite of Cold Exposure}

A recent study from our laboratory investigated the effects of exercise on the structural lipid profile of BAT using MS/MS ${ }^{\mathrm{ALL}}$ lipidomics [71]. After 3 weeks of voluntary wheel-cage running, the overall abundance of TAGs was significantly reduced in BAT after exercise, an effect that was not observed after cold exposure [61]. In fact, in contrast to cold exposure, exercise reduced the expression of genes involved in fatty acid biosynthesis (Acaca, $S c d 1$, Agpat3, Dgkd, and Mlxipl). After cold exposure, BAT increases TAG production in order to use energy from the TAGs as heat and contribute to non-shivering thermogenesis. Conversely, thermogenesis in BAT during or immediately after exercise remains unchanged, thus the de novo synthesis of FFA and TAG would not be necessary to sustain BAT activity.

Consistently, the phospholipid pathway appears to be regulated differently in response to exercise and cold exposure in BAT. Exercise increases specific acyl chains 36:2 in phosphatidylcholines (PC), 40:5 and 40:6 acyl chains in phosphatidylethanolamine (PE), and 16:0 and 16:1 acyl chains in phosphatidylserine (PS) species [61]. The molecular species that are increased after exercise are distinct from those upregulated after cold exposure (18:0, 18:1, and 18:2 acyl chains) [61]. The expression of genes involved in phospholipid metabolism (Agpat3, Gpd1, Lgpat1, Ptdss2, and Pld1) are also significantly decreased in BAT after exercise. Interestingly, and in contrast to chronic 
cold exposure [65,66] (Table 1), the overall abundance of lysophosphatidylglycerols (LPG) and $\mathrm{CL}$ were decreased after chronic exercise. Despite the extensive characterization of the lipidomic changes in response to both cold and exercise, to our knowledge no studies have investigated the role of the metabolic differences and specific molecular targets that regulate the remodeling of structural lipids [106]. Taken together, these studies indicate that cold and exercise produce profound species-specific modifications to the BAT lipidome that might confer enhanced thermogenic or endocrine capabilities to BAT. Previous studies have hypothesized that the cold-induced lipidomic changes in BAT might be necessary for mitochondrial biogenesis and enhancement of mitochondrial function, independently from the thermogenic activation [65]. Furthermore, the lipidomic changes elicited by exercise training might prime not only BAT [71] but also skeletal muscle mitochondria [106]. Thus, the lipidomic signature in response to cold and exercise are largely required to sustain such metabolic and energetic adaptations. Despite this information, the mechanistic importance of these differences is still unclear and the physiological effects of cold- and exercise-induced changes in the BAT lipidome remain important topics of investigation (Figure 1).

\section{6. "Batokines": Secreted Factors Released by Cold and Exercise}

Adipokines released from BAT, or "batokines," can act locally or systemically to improve metabolic health [20]. In this section we will review several batokines that are affected by cold, exercise, or both.

\subsection{2,13-diHOME Increases FA Uptake in BAT and Skeletal Muscle}

Circulating lipids have been identified to be released from certain tissues and act locally or systemically to promote glucose tolerance and insulin sensitivity. A recent study investigated the effects of cold on signaling lipids in humans and rodents [107]. Using mass-spectrometry based lipidomics, the lipokine 12,13-diHOME was identified to be released from BAT after $1 \mathrm{~h}$ of cold exposure in both rodents $\left(4^{\circ} \mathrm{C}\right)$ and humans $\left(14^{\circ} \mathrm{C}\right)$. Expression of epoxide hydrolase 1 and epoxide hydrolase 2 (Ephx1 and Ephx2), the enzymes involved in 12,13-diHOME synthesis from linoleic acid, were significantly increased in BAT in response to cold exposure. The release of 12,13-diHOME increased fatty acid uptake, lipolysis, and thermogenesis in BAT. In addition, prolonged treatment with 12,13-diHOME in obese mice decreased circulating triglyceride levels. This is the first study to identify a signaling lipid released from BAT in response to cold that functions in an autocrine-paracrine mechanism to improve metabolic health.

A recent study in our lab investigated the effects of exercise on circulating lipokines in rodents and humans [27]. Surprisingly, we determined that acute physical exercise in humans and mice increased the circulating levels of the lipokine 12,13-diHOME. When BAT was surgically removed from mice and the mice underwent an acute bout of exercise, there was no increase in 12,13-diHOME, indicating that BAT was the source of this lipokine. 12,13-diHOME was positively correlated with $\mathrm{VO}_{2}$ peak and negatively correlated with BMI. Furthermore, acute treatment with 12,13-diHOME in mice in vivo increased skeletal muscle fatty acid uptake and oxidation but had no effect on glucose uptake. These data are the first to identify an endocrine role for BAT in response to exercise and indicate a novel mechanism for BAT-skeletal muscle cross-talk.

The parallels between the effects of exercise and cold exposure on 12,13-diHOME are important and somewhat unexpected [27]. First, both short term and chronic cold exposure or exercise increase the concentration of circulating 12,13-diHOME to a similar extent. Both cold exposure and exercise increase 12,13-diHOME in BAT, which is the tissue source of circulating 12,13-diHOME. This is unexpected because while cold exposure is a well-established tool to stimulate BAT activity, most investigations have shown that exercise training has an opposite effect than cold exposure and decreases BAT activity in humans and rodents [32,33]. It is possible that that cold exposure causes the release of 12,13-diHOME from BAT to act in an autocrine manner and provide fuel for the BAT, while exercise causes the release of 12,13-diHOME from BAT to act in an endocrine manner, stimulating uptake of fatty acids into the working skeletal muscle [27]. Another potential hypothesis is that exercise 
increases the sympathetic tone and vascularization of BAT, similar to cold exposure, despite the weak activation of thermogenesis [38]. This could allow for a similar effect of exercise and cold exposure on 12,13-diHOME (Figure 1).

\subsection{Fibroblast Growth Factor 21 (FGF21) Regulates Glucose and Lipid Metabolism}

One of the most well-investigated batokines is FGF21, a peptide hormone that is involved in both lipid and glucose metabolism [108]. The predominant source of FGF21 is the liver, but FGF21 is also highly expressed in WAT [109] and BAT [110]. FGF21 knockout (KO) mice show larger lipid droplets in BAT and cold intolerance [111]. Liver-derived FGF21 can activate thermogenesis in neonatal BAT [112], and treatment with FGF21 in mice increases expression of UCP1 [113], improves insulin sensitivity, and lowers blood glucose and lipids [108]. FGF21 effects in BAT include acutely enhancing in insulin sensitivity, glucose uptake, and accelerated lipoprotein catabolism [110,114,115].

Short-term cold exposure in rodents increases the expression and release of FGF21 from BAT [108, 110] via a cAMP-related mechanism. Infusion of FGF21 in mice increases energy expenditure and core temperature, likely indicating catabolism of glucose and fatty acids and possibly thermogenic activation of BAT $[113,116,117]$. A study comparing wild type (WT) mice with FGF21 KO also demonstrated that cold exposure $\left(18{ }^{\circ} \mathrm{C}\right.$ to $5{ }^{\circ} \mathrm{C}$ for 5 weeks) increases FGF21 gene expression in BAT of WT but FGF21 is not required for BAT cold adaptation in FGF21 KO [118]. In humans, FGF21 is highly expressed in BAT [119]. Mild cold exposure $\left(19^{\circ} \mathrm{C}\right)$ increases circulating FGF1 levels [120], and cold induced circulating FGF21 levels are associated with increased BAT activity [121,122]. A clinical model of cold exposure ( $12 \mathrm{~min}$ from $18{ }^{\circ} \mathrm{C}$ to $12{ }^{\circ} \mathrm{C}$ ) in healthy human subjects increased plasma FGF21, but the source of the circulating FGF21 was not determined [122]. Thus, cold exposure can increase FGF21 expression in BAT of rodents and humans and it is possibly associated with increased BAT function and increased glucose and fatty acids utilization; however, FGF21 is not essential for the maintenance of metabolic homeostasis in the cold adaptation [118].

Acute exercise increased FGF21 in the serum and in liver, but not in white adipose tissue of rodents [123], while the role of BAT-released FGF21 in response to exercise was not established. Acute [123] and chronic exercise also increased serum FGF21 in healthy human subjects [124], and the liver was indicated as the primary source of FGF21 in response to exercise [123]. The effects of exercise in BAT FGF21 expression and release was not yet determined. While there is no evidence comparing BAT-derived FGF21 to recombinant FGF21 administration, a long-acting analog of FGF21 (PF-05231023) has demonstrated to be effective at reducing body weight and serum TAG, while simultaneously increasing the anti-inflammatory adipokine adiponectin in non-human primates and humans [125]. Additionally, we have demonstrated that BAT transplantation leads to improved glucose tolerance, increased insulin sensitivity, reduced body weight and fat mass, and reversal of high fat-diet (HFD)-induced insulin resistance in mice [20]. To our knowledge, FGF21 isolated from BAT has not been compared to recombinant FGF21 in mice or humans. Future studies should compare the cold- and exercise-induced FGF21 with a synthetic FGF21 to assess the translatability of these therapeutic strategies. Taken together, these data show that FGF21 can be released from BAT and plays an important role in glucose and lipid metabolism. FGF21 is regulated by both cold and exercise, and while cold increases FGF21 release from BAT in rodents, it is unclear whether the tissue responsible for the increase in response to exercise is BAT; this will be the topic of future investigations (Figure 1).

\subsection{Vascular Endothelial Growth Factor A (VEGFA) Mediates Thermogenic Adaptations}

VEGFA is an angiogenic growth factor that stimulates vascular endothelial cell activation, proliferation, and migration [126]. VEGFA is also a batokine that acts in a paracrine fashion to regulate vascularization [56] and activate thermogenesis. Studies in both rodents [56] and humans [45] demonstrate a direct relationship between increased VEGFA, vascularization in BAT, and increased thermogenesis. 
Cold exposure studies utilizing transgenic mouse models have clearly illustrated the importance of VEGFA in thermogenesis. Overexpression of VEGFA increases vascularization of BAT and expression of both Ucp1 and Pgc1 $1 \alpha$ [57], increasing thermogenic capacity upon cold exposure. Alternatively, VEGFA-null mice display functional decrements in regards to thermogenesis due to reduced vascularization and mitochondrial function in BAT [127].

To the best of our knowledge, studies have not looked at the effects of exercise on VEGFA specific to BAT. However, VEGFA is increased in WAT in response to exercise in both mice $[128,129]$ and humans [130]. Because VEGFA is a crucial protein that regulates adaptations to exercise training and improvements in aerobic capacity [131], it is possible that exercise has a similar affect to increase VEGFA in BAT. It is tempting to hypothesize that adaptations to VEGFA content in response to exercise may be related to BAT activity, but this has not yet been investigated; this will be an important focus of future investigations (Figure 1).

\section{Cold and Exercise Induce a "Beiging" of White Adipose Tissue (WAT)}

In addition to the stimulation of BAT, induction of brown-like or "beige" cells by cold and exercise has gained notoriety given its high therapeutic potential [132-134]. Since the discovery of cold-induced BAT in adult humans, researchers have studied biopsies of ${ }^{18}$ FDG-positive neck fat depots to establish the genetic, molecular, and functional signature of human BAT to understand whether these adipocytes recapitulate aspects of brown or brown-like adipose depots-the so called beige adipose. Beige fat cells originate from WAT and share many characteristics with brown adipocytes, such as a multilocular lipid droplets, increased mitochondrial density, and high levels of UCP1, together with increased capacity for fuel oxidation and thermogenesis [135-138]. Currently, there is evidence that human BAT displays either a classical brown or a beige signature, or a combination of both, which explains the heterogeneous responses [138-143]. Interestingly, both cold and exercise are important inducers of the beige program or "beiging" of white adipocytes $[28,144]$. Cold- and exercise-induced beiging increases the number of metabolically active cells within WAT depots, which in turn constitutes an effective strategy to combat obesity and T2DM [132-134]. Increase in the number and the activity of beige cells, as well as the reprogramming of cellular beige precursors might be responsible, at least in part, for the beneficial effects of cold and exercise on metabolism. Here, we will summarize the role of cold exposure and exercise training on adipose tissue beiging.

\subsection{Long-Term Cold Exposure Induces Beiging of WAT}

Chronic cold exposure induces sympathetic activation and thermogenic response in WAT. The interaction of norepinephrine with $\beta 3$-ARs present on the membrane of white adipocytes initiates a cascade that leads to the overexpression of UCP1 and other thermogenic proteins $[137,145]$. Recent studies have demonstrated that cold exposure could also stimulate beiging of WAT through the batokine signaling such as interleukin 6 (IL-6), neuregulin 4 (Nrg4), and FGF21 [146-148], and the myokine irisin [149]; these browning agents have been previously reviewed [150-152]. Studies in rodents demonstrate that cold adaptation $\left(4{ }^{\circ} \mathrm{C}\right.$ to $\left.6{ }^{\circ} \mathrm{C}\right)$ results in beiging of subcutaneous WAT (scWAT) with improved metabolic activity [153-157].

Although experiments in rodents have shown a profound effect of cold on beiging, experimental evidence in humans remains inconclusive. Studies with cultured healthy human scWAT cells demonstrated that long-term cold exposure increases PGC1 $\alpha$, UCP1 expression, and mitochondrial activity, which are all defining features of beige cells $[158,159]$. In spite of this, a study of cold acclimation in healthy humans $\left(15{ }^{\circ} \mathrm{C}-16{ }^{\circ} \mathrm{C}, 2 \mathrm{~h}\right.$ to $6 \mathrm{~h} /$ day, 10 days $)$ did not show beiging of scWAT [160]. These disparities in the results are likely associated with the duration of cold exposure. While it seems that long term cold exposure can promote beiging of scWAT in humans, further studies are needed to define the length of cold exposure needed to induce beiging in humans, and whether these observations can be translated to subjects with obesity and T2DM. 


\subsection{Effects of Exercise Training on the Beiging of WAT}

In recent years, studies in rodents have extensively demonstrated that chronic exercise, through various mechanisms including sympathetic activation $[145,161]$ and secreted factors myokines, induces a beiging of WAT (irisin, IL-6, and meteorin-like (Metrnl)) [162-166]. This exercise-induced beiging is characterized by increased markers such as Ucp1, Pgc1 $\alpha, \operatorname{Prdm} 16$, and Cidea in lean rodents $[73,129,162,167]$. In HFD-induced obese animals, chronic exercise shows conflicting results on beiging. Some studies indicate that exercise increased beiging markers [32,168], whereas another found a neutral effect [169], and some observed decreased beiging markers following chronic exercise training [170]. These contradictory results are likely explained by differences in the modality and duration of exercise, which warrants further investigation.

The exercise-induced beiging in humans remains largely undefined $[33,171]$. Studies assessing the effect of chronic exercise on beiging did not observe such effects in scWAT biopsies in healthy $[33,171,172]$ or obese individuals $[173,174]$. A recent study however, demonstrated a significant effect of exercise training on beiging markers (Ucp1 and Cpt1) in abdominal scWAT across weight spectrums, despite the lack of effects on insulin sensitivity [175]. Additional studies are necessary to assess different exercise types, duration, frequency, and intensity, as well as gender, age, and health status, and standardization of adipose tissue sampled, and methods used to assess beiging of WAT.

Taken together, both cold and exercise can induce beiging in lean rodents leading to increases in metabolically active adipose tissue. In humans, however, the clinical evidence remains insufficient to suggest that both stimuli have the positive effects on WAT beiging.

\section{Conclusions and Future Perspectives}

Over the last decade BAT has garnered great interest as a therapeutic target to combat obesity and T2DM as numerous studies have established an association between BAT activity and metabolic health. Both cold exposure and exercise represent potential tools to impact BAT function by altering its activity and metabolism. Cold exposure is an effective method to activate the thermogenic activity of BAT, increase energy expenditure in BAT, and improve glucose homeostasis, insulin sensitivity, and lipid metabolism. Exercise is an important therapeutic tool to regulate whole-body glucose homeostasis, but the role of exercise on glucose uptake, lipid metabolism, and mitochondrial activity in BAT is unclear. There are several potential reasons for the conflicting effects of exercise on BAT activation, including differences in modality and duration of exercise, strain of mouse used during the investigation, and different measurements of BAT activation. Thus, greater standardization of testing protocols is needed to make true comparisons and interpretations of the data.

Because of the distinct effects of cold and exercise on BAT metabolism, there is a great need to investigate the synergistic effects of a combined model of cold and exercise. An important overlap exists between the effects of cold and exercise on multiple batokines, which emphasizes the need for the investigation of the synergistic effects of cold and exercise on batokine release. Because both cold exposure and exercise can stimulate the release of batokines that leads to glucose and fatty acid metabolism improvement (i.e., FGF21 and 12,13-diHOME), this new area of research will likely continue to drive interest in the field of BAT metabolism, thereby increasing our knowledge and ability to harness the full potential of BAT as a therapeutic tool to ameliorate metabolic diseases, specifically T2DM. Interestingly, endurance athletes have begun to combine extreme but acute $(\approx 3$ $\mathrm{min}$ ) bouts of cold exposure called "cryotherapy" with their training schedules as a means of speeding recovery [176]. This could be a potential therapeutic tool to combat metabolic abnormalities, for instance, targeting BAT activation in type 2 diabetic patient populations leading to concomitant improvements in insulin sensitivity. It is important to note that some obese patients, especially cases of morbid obesity, are related to the difficulty in performing physical exercises, considering the respiratory difficulty and joint diseases associated with excess body mass $[177,178]$. In addition, cold exposure protocols can be quite unsuitable and uncomfortable for obese patients [137]. Thus, these limitations 
need to be taken into consideration for the elaboration of a therapeutic protocol associating exercise and cold exposure in obese individuals.

Future studies will fully elucidate the mechanisms through which these treatments cause adaptations to BAT and affect metabolic health. As both therapies can improve insulin sensitivity, a combined treatment may be an attractive strategy to employ comprehensive lifestyle modifications for obese patients with a high risk of developing T2DM and other metabolic derangements.

Funding: This work was supported by National Institutes of Health Grants R01-HL138738 and R56-AG060542 to K.I.S. and 5T32HL0803-09 to J.D.W.

Conflicts of Interest: The authors declare no conflict of interest.

\section{References}

1. Hruby, A.; Hu, F.B. The Epidemiology of Obesity: A Big Picture. Pharmacoeconomics 2015, 33, 673-689. [CrossRef] [PubMed]

2. Arroyo-Johnson, C.; Mincey, K.D. Obesity Epidemiology Worldwide. Gastroenterol. Clin. N. Am. 2016, 45, 571-579. [CrossRef] [PubMed]

3. World Health Organization. Obesity and Overweight. Available online: http://www.who.int/news-room/ fact-sheets/detail/obesity-and-overweight (accessed on 20 December 2018).

4. Hill, J.O.; Wyatt, H.R.; Peters, J.C. Energy balance and obesity. Circulation 2012, 126, 126-132. [CrossRef]

5. Swinburn, B.A.; Caterson, I.; Seidell, J.C.; James, W.P. Diet, nutrition and the prevention of excess weight gain and obesity. Public Health Nutr. 2004, 7, 123-146. [PubMed]

6. Kelley, D.E.; Mokan, M.; Mandarino, L.J. Intracellular defects in glucose metabolism in obese patients with NIDDM. Diabetes 1992, 41, 698-706. [CrossRef] [PubMed]

7. Goodpaster, B.H.; Sparks, L.M. Metabolic Flexibility in Health and Disease. Cell Metab. 2017, 25, 1027-1036. [CrossRef]

8. Kelley, D.E. Skeletal muscle triglycerides: An aspect of regional adiposity and insulin resistance. Ann. N. Y. Acad. Sci. 2002, 967, 135-145. [CrossRef]

9. Ferguson, R.D.; Gallagher, E.J.; Scheinman, E.J; Damouni, R.; LeRoith, D. The epidemiology and molecular mechanisms linking obesity, diabetes, and cancer. Vitam. Horm. 2013, 93, 51-98. [CrossRef]

10. Gallagher, E.J.; LeRoith, D. Obesity and Diabetes: The Increased Risk of Cancer and Cancer-Related Mortality. Physiol. Rev. 2015, 95, 727-748. [CrossRef]

11. Yu, E.; Ley, S.H.; Manson, J.E.; Willett, W.; Satija, A.; Hu, F.B.; Stokes, A. Weight History and All-Cause and Cause-Specific Mortality in Three Prospective Cohort Studies. Ann. Intern. Med. 2017, 166, 613-620. [CrossRef]

12. Poher, A.L.; Altirriba, J.; Veyrat-Durebex, C.; Rohner-Jeanrenaud, F. Brown adipose tissue activity as a target for the treatment of obesity/insulin resistance. Front. Physiol. 2015, 6, 4. [CrossRef] [PubMed]

13. Bouillaud, F.; Ricquier, D.; Thibault, J.; Weissenbach, J. Molecular approach to thermogenesis in brown adipose tissue: cDNA cloning of the mitochondrial uncoupling protein. Proc. Natl. Acad. Sci. USA 1985, 82, 445-448. [CrossRef] [PubMed]

14. Fedorenko, A.; Lishko, P.V.; Kirichok, Y. Mechanism of fatty-acid-dependent UCP1 uncoupling in brown fat mitochondria. Cell 2012, 151, 400-413. [CrossRef] [PubMed]

15. Carpentier, A.C.; Blondin, D.P.; Virtanen, K.A.; Richard, D.; Haman, F.; Turcotte, E.E. Brown Adipose Tissue Energy Metabolism in Humans. Front. Endocrinol. (Lausanne) 2018, 9, 447. [CrossRef] [PubMed]

16. Nicholls, D.G.; Locke, R.M. Thermogenic mechanisms in brown fat. Physiol. Rev. 1984, 64, 1-64. [CrossRef] [PubMed]

17. Lowell, B.B.; Spiegelman, B.M. Towards a molecular understanding of adaptive thermogenesis. Nature 2000, 404, 652-660. [CrossRef] [PubMed]

18. Klingenberg, M. Mechanism and evolution of the uncoupling protein of brown adipose tissue. Trends Biochem. Sci. 1990, 15, 108-112. [CrossRef]

19. Bartelt, A.; Bruns, O.T.; Reimer, R.; Hohenberg, H.; Ittrich, H.; Peldschus, K.; Kaul, M.G.; Tromsdorf, U.I.; Weller, H.; Waurisch, C.; et al. Brown adipose tissue activity controls triglyceride clearance. Nat. Med. 2011, 17, 200-205. [CrossRef] 
20. Stanford, K.I.; Middelbeek, R.J.; Townsend, K.L.; An, D.; Nygaard, E.B.; Hitchcox, K.M.; Markan, K.R.; Nakano, K.; Hirshman, M.F.; Tseng, Y.H.; et al. Brown adipose tissue regulates glucose homeostasis and insulin sensitivity. J. Clin. Investig. 2013, 123, 215-223. [CrossRef]

21. Berbee, J.F.; Boon, M.R.; Khedoe, P.P.; Bartelt, A.; Schlein, C.; Worthmann, A.; Kooijman, S.; Hoeke, G.; Mol, I.M.; John, C.; et al. Brown fat activation reduces hypercholesterolaemia and protects from atherosclerosis development. Nat. Commun. 2015, 6, 6356. [CrossRef]

22. Cannon, B.; Nedergaard, J. Brown adipose tissue: Function and physiological significance. Physiol. Rev. 2004, 84, 277-359. [CrossRef] [PubMed]

23. Marlatt, K.L.; Ravussin, E. Brown Adipose Tissue: An Update on Recent Findings. Curr. Obes. Rep. 2017, 6, 389-396. [CrossRef] [PubMed]

24. Nedergaard, J.; Golozoubova, V.; Matthias, A.; Asadi, A.; Jacobsson, A.; Cannon, B. UCP1: The only protein able to mediate adaptive non-shivering thermogenesis and metabolic inefficiency. Biochim. Biophys. Acta 2001, 1504, 82-106. [CrossRef]

25. Bonadonna, R.C.; Del Prato, S.; Saccomani, M.P.; Bonora, E.; Gulli, G.; Ferrannini, E.; Bier, D.; Cobelli, C.; DeFronzo, R.A. Transmembrane glucose transport in skeletal muscle of patients with non-insulin-dependent diabetes. J. Clin. Investig. 1993, 92, 486-494. [CrossRef] [PubMed]

26. Joyner, M.J.; Green, D.J. Exercise protects the cardiovascular system: Effects beyond traditional risk factors. J. Physiol. 2009, 587, 5551-5558. [CrossRef] [PubMed]

27. Stanford, K.I.; Lynes, M.D.; Takahashi, H.; Baer, L.A.; Arts, P.J.; May, F.J.; Lehnig, A.C.; Middelbeek, R.J.W.; Richard, J.J.; So, K.; et al. 12,13-diHOME: An Exercise-Induced Lipokine that Increases Skeletal Muscle Fatty Acid Uptake. Cell Metab. 2018, 27, 1111-1120.e1113. [CrossRef] [PubMed]

28. Stanford, K.I.; Middelbeek, R.J.; Goodyear, L.J. Exercise Effects on White Adipose Tissue: Beiging and Metabolic Adaptations. Diabetes 2015, 64, 2361-2368. [CrossRef] [PubMed]

29. De Las Heras, N.; Klett-Mingo, M.; Ballesteros, S.; Martin-Fernandez, B.; Escribano, O.; Blanco-Rivero, J.; Balfagon, G.; Hribal, M.L.; Benito, M.; Lahera, V.; et al. Chronic Exercise Improves Mitochondrial Function and Insulin Sensitivity in Brown Adipose Tissue. Front. Physiol. 2018, 9, 1122. [CrossRef]

30. Xu, X.; Ying, Z.; Cai, M.; Xu, Z.; Li, Y.; Jiang, S.Y.; Tzan, K.; Wang, A.; Parthasarathy, S.; He, G.; et al. Exercise ameliorates high-fat diet-induced metabolic and vascular dysfunction, and increases adipocyte progenitor cell population in brown adipose tissue. Am. J. Physiol. Regul. Integr. Comp. Physiol. 2011, 300, R1115-R1125. [CrossRef]

31. Yoshioka, K.; Yoshida, T.; Wakabayashi, Y.; Nishioka, H.; Kondo, M. Effects of exercise training on brown adipose tissue thermogenesis in ovariectomized obese rats. Endocrinol. Jpn. 1989, 36, 403-408. [CrossRef]

32. Wu, M.V.; Bikopoulos, G.; Hung, S.; Ceddia, R.B. Thermogenic capacity is antagonistically regulated in classical brown and white subcutaneous fat depots by high fat diet and endurance training in rats: Impact on whole-body energy expenditure. J. Biol. Chem. 2014, 289, 34129-34140. [CrossRef] [PubMed]

33. Vosselman, M.J.; Hoeks, J.; Brans, B.; Pallubinsky, H.; Nascimento, E.B.; van der Lans, A.A.; Broeders, E.P.; Mottaghy, F.M.; Schrauwen, P.; van Marken Lichtenbelt, W.D. Low brown adipose tissue activity in endurance-trained compared with lean sedentary men. Int. J. Obes. (Lond.) 2015, 39, 1696-1702. [CrossRef] [PubMed]

34. Sullo, A.; Brizzi, G.; Maffulli, N. Triiodothyronine deiodinating activity in brown adipose tissue after short cold stimulation test in trained and untrained rats. Physiol. Res. 2004, 53, 69-76. [PubMed]

35. Crandall, J.P.; Knowler, W.C.; Kahn, S.E.; Marrero, D.; Florez, J.C.; Bray, G.A.; Haffner, S.M.; Hoskin, M.; Nathan, D.M. The prevention of type 2 diabetes. Nat. Clin. Pract. Endocrinol. Metab. 2008, 4, 382-393. [CrossRef] [PubMed]

36. Myers, J. Cardiology patient pages. Exercise and cardiovascular health. Circulation 2003, 107, e2-e5. [CrossRef] [PubMed]

37. Sanchez-Delgado, G.; Martinez-Tellez, B.; Olza, J.; Aguilera, C.M.; Gil, A.; Ruiz, J.R. Role of Exercise in the Activation of Brown Adipose Tissue. Ann. Nutr. Metab. 2015, 67, 21-32. [CrossRef] [PubMed]

38. De Matteis, R.; Lucertini, F.; Guescini, M.; Polidori, E.; Zeppa, S.; Stocchi, V.; Cinti, S.; Cuppini, R. Exercise as a new physiological stimulus for brown adipose tissue activity. Nutr. Metab. Cardiovasc. Dis. 2013, 23, 582-590. [CrossRef] 
39. Cypess, A.M.; Lehman, S.; Williams, G.; Tal, I.; Rodman, D.; Goldfine, A.B.; Kuo, F.C.; Palmer, E.L.; Tseng, Y.H.; Doria, A.; et al. Identification and importance of brown adipose tissue in adult humans. N. Engl. J. Med. 2009, 360, 1509-1517. [CrossRef]

40. Baba, S.; Engles, J.M.; Huso, D.L.; Ishimori, T.; Wahl, R.L. Comparison of uptake of multiple clinical radiotracers into brown adipose tissue under cold-stimulated and nonstimulated conditions. J. Nucl. Med. 2007, 48, 1715-1723. [CrossRef]

41. Shibata, H.; Perusse, F.; Vallerand, A.; Bukowiecki, L.J. Cold exposure reverses inhibitory effects of fasting on peripheral glucose uptake in rats. Am. J. Physiol. 1989, 257, R96-R101. [CrossRef]

42. Shimizu, Y.; Nikami, H.; Tsukazaki, K.; Machado, U.F.; Yano, H.; Seino, Y.; Saito, M. Increased expression of glucose transporter GLUT-4 in brown adipose tissue of fasted rats after cold exposure. Am. J. Physiol. 1993, 264, E890-E895. [CrossRef] [PubMed]

43. Nedergaard, J.; Bengtsson, T.; Cannon, B. New powers of brown fat: Fighting the metabolic syndrome. Cell Metab. 2011, 13, 238-240. [CrossRef] [PubMed]

44. Matsushita, M.; Yoneshiro, T.; Aita, S.; Kameya, T.; Sugie, H.; Saito, M. Impact of brown adipose tissue on body fatness and glucose metabolism in healthy humans. Int. J. Obes. (Lond.) 2014, 38, 812-817. [CrossRef] [PubMed]

45. Orava, J.; Nuutila, P.; Lidell, M.E.; Oikonen, V.; Noponen, T.; Viljanen, T.; Scheinin, M.; Taittonen, M.; Niemi, T.; Enerback, S.; et al. Different metabolic responses of human brown adipose tissue to activation by cold and insulin. Cell Metab. 2011, 14, 272-279. [CrossRef] [PubMed]

46. van Marken Lichtenbelt, W.D.; Vanhommerig, J.W.; Smulders, N.M.; Drossaerts, J.M.; Kemerink, G.J.; Bouvy, N.D.; Schrauwen, P.; Teule, G.J. Cold-activated brown adipose tissue in healthy men. N. Engl. J. Med. 2009, 360, 1500-1508. [CrossRef] [PubMed]

47. Chondronikola, M.; Volpi, E.; Borsheim, E.; Chao, T.; Porter, C.; Annamalai, P.; Yfanti, C.; Labbe, S.M.; Hurren, N.M.; Malagaris, I.; et al. Brown Adipose Tissue Is Linked to a Distinct Thermoregulatory Response to Mild Cold in People. Front. Physiol. 2016, 7, 129. [CrossRef] [PubMed]

48. Hanssen, M.J.; Hoeks, J.; Brans, B.; van der Lans, A.A.; Schaart, G.; van den Driessche, J.J.; Jorgensen, J.A.; Boekschoten, M.V.; Hesselink, M.K.; Havekes, B.; et al. Short-term cold acclimation improves insulin sensitivity in patients with type 2 diabetes mellitus. Nat. Med. 2015, 21, 863-865. [CrossRef]

49. Hanssen, M.J.; van der Lans, A.A.; Brans, B.; Hoeks, J.; Jardon, K.M.; Schaart, G.; Mottaghy, F.M.; Schrauwen, P.; van Marken Lichtenbelt, W.D. Short-term Cold Acclimation Recruits Brown Adipose Tissue in Obese Humans. Diabetes 2016, 65, 1179-1189. [CrossRef]

50. Chondronikola, M.; Volpi, E.; Borsheim, E.; Porter, C.; Saraf, M.K.; Annamalai, P.; Yfanti, C.; Chao, T.; Wong, D.; Shinoda, K.; et al. Brown Adipose Tissue Activation Is Linked to Distinct Systemic Effects on Lipid Metabolism in Humans. Cell Metab. 2016, 23, 1200-1206. [CrossRef]

51. Nedergaard, J.; Alexson, S.; Cannon, B. Cold adaptation in the rat: Increased brown fat peroxisomal beta-oxidation relative to maximal mitochondrial oxidative capacity. Am. J. Physiol. 1980, 239, C208-C216. [CrossRef]

52. Moriya, K.; Leblanc, J.; Arnold, J. Effects of exercise and intermittent cold exposure on shivering and nonshivering thermogenesis in rats. Jpn. J. Physiol. 1987, 37, 715-727. [CrossRef] [PubMed]

53. LeBlanc, J.; Diamond, P. Interaction between exercise training and cold acclimation in rats. Eur. J. Appl. Physiol. Occup. Physiol. 1988, 57, 89-92. [CrossRef] [PubMed]

54. Yu, X.X.; Lewin, D.A.; Forrest, W.; Adams, S.H. Cold elicits the simultaneous induction of fatty acid synthesis and beta-oxidation in murine brown adipose tissue: Prediction from differential gene expression and confirmation in vivo. FASEB J. 2002, 16, 155-168. [CrossRef] [PubMed]

55. Moura, M.A.; Festuccia, W.T.; Kawashita, N.H.; Garofalo, M.A.; Brito, S.R.; Kettelhut, I.C.; Migliorini, R.H. Brown adipose tissue glyceroneogenesis is activated in rats exposed to cold. Pflugers Arch. 2005, 449, 463-469. [CrossRef] [PubMed]

56. Xue, Y.; Petrovic, N.; Cao, R.; Larsson, O.; Lim, S.; Chen, S.; Feldmann, H.M.; Liang, Z.; Zhu, Z.; Nedergaard, J.; et al. Hypoxia-independent angiogenesis in adipose tissues during cold acclimation. Cell Metab. 2009, 9, 99-109. [CrossRef] [PubMed]

57. Sun, K.; Kusminski, C.M.; Luby-Phelps, K.; Spurgin, S.B.; An, Y.A.; Wang, Q.A.; Holland, W.L.; Scherer, P.E. Brown adipose tissue derived VEGF-A modulates cold tolerance and energy expenditure. Mol. Metab. 2014, 3, 474-483. [CrossRef] [PubMed] 
58. Nie, Y.; Yan, Z.; Yan, W.; Xia, Q.; Zhang, Y. Cold exposure stimulates lipid metabolism, induces inflammatory response in the adipose tissue of mice and promotes the osteogenic differentiation of BMMSCs via the p38 MAPK pathway in vitro. Int. J. Clin. Exp. Pathol. 2015, 8, 10875-10886.

59. Yu, J.; Zhang, S.; Cui, L.; Wang, W.; Na, H.; Zhu, X.; Li, L.; Xu, G.; Yang, F.; Christian, M.; et al. Lipid droplet remodeling and interaction with mitochondria in mouse brown adipose tissue during cold treatment. Biochim. Biophys. Acta 2015, 1853, 918-928. [CrossRef]

60. Gospodarska, E.; Nowialis, P.; Kozak, L.P. Mitochondrial turnover: A phenotype distinguishing brown adipocytes from interscapular brown adipose tissue and white adipose tissue. J. Biol. Chem. 2015, 290, 8243-8255. [CrossRef]

61. Marcher, A.B.; Loft, A.; Nielsen, R.; Vihervaara, T.; Madsen, J.G.; Sysi-Aho, M.; Ekroos, K.; Mandrup, S. RNA-Seq and Mass-Spectrometry-Based Lipidomics Reveal Extensive Changes of Glycerolipid Pathways in Brown Adipose Tissue in Response to Cold. Cell Rep. 2015, 13, 2000-2013. [CrossRef]

62. Jia, R.; Luo, X.Q.; Wang, G.; Lin, C.X.; Qiao, H.; Wang, N.; Yao, T.; Barclay, J.L.; Whitehead, J.P.; Luo, X.; et al. Characterization of cold-induced remodelling reveals depot-specific differences across and within brown and white adipose tissues in mice. Acta Physiol. (Oxf.) 2016, 217, 311-324. [CrossRef]

63. Okada, K.; LeClair, K.B.; Zhang, Y.; Li, Y.; Ozdemir, C.; Krisko, T.I.; Hagen, S.J.; Betensky, R.A.; Banks, A.S.; Cohen, D.E. Thioesterase superfamily member 1 suppresses cold thermogenesis by limiting the oxidation of lipid droplet-derived fatty acids in brown adipose tissue. Mol. Metab. 2016, 5, 340-351. [CrossRef]

64. Bal, N.C.; Singh, S.; Reis, F.C.G.; Maurya, S.K.; Pani, S.; Rowland, L.A.; Periasamy, M. Both brown adipose tissue and skeletal muscle thermogenesis processes are activated during mild to severe cold adaptation in mice. J. Biol. Chem. 2017, 292, 16616-16625. [CrossRef]

65. Lynes, M.D.; Shamsi, F.; Sustarsic, E.G.; Leiria, L.O.; Wang, C.H.; Su, S.C.; Huang, T.L.; Gao, F.; Narain, N.R.; Chen, E.Y.; et al. Cold-Activated Lipid Dynamics in Adipose Tissue Highlights a Role for Cardiolipin in Thermogenic Metabolism. Cell Rep. 2018, 24, 781-790. [CrossRef] [PubMed]

66. Sustarsic, E.G.; Ma, T.; Lynes, M.D.; Larsen, M.; Karavaeva, I.; Havelund, J.F.; Nielsen, C.H.; Jedrychowski, M.P.; Moreno-Torres, M.; Lundh, M.; et al. Cardiolipin Synthesis in Brown and Beige Fat Mitochondria Is Essential for Systemic Energy Homeostasis. Cell Metab. 2018, 28, 159-174.e111. [CrossRef]

67. Wickler, S.J.; Stern, J.S.; Glick, Z.; Horwitz, B.A. Thermogenic capacity and brown fat in rats exercise-trained by running. Metabolism 1987, 36, 76-81. [CrossRef]

68. Oh-ishi, S.; Kizaki, T.; Toshinai, K.; Haga, S.; Fukuda, K.; Nagata, N.; Ohno, H. Swimming training improves brown-adipose-tissue activity in young and old mice. Mech. Ageing Dev. 1996, 89, 67-78. [CrossRef]

69. Ignacio, D.L.; Fortunato, R.S.; Neto, R.A.; da Silva Silvestre, D.H.; Nigro, M.; Frankenfeld, T.G.; Werneck-de-Castro, J.P.; Carvalho, D.P. Blunted response of pituitary type 1 and brown adipose tissue type 2 deiodinases to swimming training in ovariectomized rats. Horm. Metab. Res. 2012, 44, 797-803. [CrossRef]

70. Ramos, S.V.; Turnbull, P.C.; MacPherson, R.E. Adipose tissue depot specific differences of PLIN protein content in endurance trained rats. Adipocyte 2016, 5, 212-223. [CrossRef]

71. May, F.J.; Baer, L.A.; Lehnig, A.C.; So, K.; Chen, E.Y.; Gao, F.; Narain, N.R.; Gushchina, L.; Rose, A.; Doseff, A.I.; et al. Lipidomic Adaptations in White and Brown Adipose Tissue in Response to Exercise Demonstrate Molecular Species-Specific Remodeling. Cell Rep. 2017, 18, 1558-1572. [CrossRef]

72. Barbosa, M.A.; Guerra-Sa, R.; De Castro, U.G.M.; de Lima, W.G.; Dos Santos, R.A.S.; Campagnole-Santos, M.J.; Alzamora, A.C. Physical training improves thermogenesis and insulin pathway, and induces remodeling in white and brown adipose tissues. J. Physiol. Biochem. 2018, 74, 441-454. [CrossRef] [PubMed]

73. Lehnig, A.C.; Baer, L.A.; Kitching, K.M.; Munoz, V.R.; Arts, P.J.; Sindeldecker, D.A.; May, F.J.; Lauritzen, H.P.M.M.; Goodyear, L.J.; Stanford, K.I. Exercise Training Induces Depot-Specific Adaptations to White and Brown Adipose Tissue. iScience 2019, 11, 425-439. [CrossRef]

74. Huttunen, P.; Hirvonen, J.; Kinnula, V. The occurrence of brown adipose tissue in outdoor workers. Eur. J. Appl. Physiol. Occup. Physiol. 1981, 46, 339-345. [CrossRef]

75. Chondronikola, M.; Volpi, E.; Borsheim, E.; Porter, C.; Annamalai, P.; Enerback, S.; Lidell, M.E.; Saraf, M.K.; Labbe, S.M.; Hurren, N.M.; et al. Brown adipose tissue improves whole-body glucose homeostasis and insulin sensitivity in humans. Diabetes 2014, 63, 4089-4099. [CrossRef] [PubMed] 
76. Blondin, D.P.; Labbe, S.M.; Noll, C.; Kunach, M.; Phoenix, S.; Guerin, B.; Turcotte, E.E.; Haman, F.; Richard, D.; Carpentier, A.C. Selective Impairment of Glucose but Not Fatty Acid or Oxidative Metabolism in Brown Adipose Tissue of Subjects With Type 2 Diabetes. Diabetes 2015, 64, 2388-2397. [CrossRef]

77. Blondin, D.P.; Tingelstad, H.C.; Noll, C.; Frisch, F.; Phoenix, S.; Guerin, B.; Turcotte, E.E.; Richard, D.; Haman, F.; Carpentier, A.C. Dietary fatty acid metabolism of brown adipose tissue in cold-acclimated men. Nat. Commun. 2017, 8, 14146. [CrossRef]

78. Singhal, V.; Maffazioli, G.D.; Ackerman, K.E.; Lee, H.; Elia, E.F.; Woolley, R.; Kolodny, G.; Cypess, A.M.; Misra, M. Effect of Chronic Athletic Activity on Brown Fat in Young Women. PLoS ONE 2016, 11, e0156353. [CrossRef]

79. Motiani, P.; Virtanen, K.A.; Motiani, K.K.; Eskelinen, J.J.; Middelbeek, R.J.; Goodyear, L.J.; Savolainen, A.M.; Kemppainen, J.; Jensen, J.; Din, M.U.; et al. Decreased insulin-stimulated brown adipose tissue glucose uptake after short-term exercise training in healthy middle-aged men. Diabetes Obes. Metab. 2017, 19, 1379-1388. [CrossRef]

80. Richter, E.A.; Hargreaves, M. Exercise, GLUT4, and skeletal muscle glucose uptake. Physiol. Rev. 2013, 93, 993-1017. [CrossRef] [PubMed]

81. Goodyear, L.J.; Kahn, B.B. Exercise, glucose transport, and insulin sensitivity. Annu. Rev. Med. 1998, 49, 235-261. [CrossRef] [PubMed]

82. Vettor, R.; Valerio, A.; Ragni, M.; Trevellin, E.; Granzotto, M.; Olivieri, M.; Tedesco, L.; Ruocco, C.; Fossati, A.; Fabris, R.; et al. Exercise training boosts eNOS-dependent mitochondrial biogenesis in mouse heart: Role in adaptation of glucose metabolism. Am. J. Physiol. Endocrinol. Metab. 2014, 306, E519-E528. [CrossRef] [PubMed]

83. Trevellin, E.; Scorzeto, M.; Olivieri, M.; Granzotto, M.; Valerio, A.; Tedesco, L.; Fabris, R.; Serra, R.; Quarta, M.; Reggiani, C.; et al. Exercise training induces mitochondrial biogenesis and glucose uptake in subcutaneous adipose tissue through eNOS-dependent mechanisms. Diabetes 2014, 63, 2800-2811. [CrossRef] [PubMed]

84. Chen, K.Y.; Cypess, A.M.; Laughlin, M.R.; Haft, C.R.; Hu, H.H.; Bredella, M.A.; Enerback, S.; Kinahan, P.E.; Lichtenbelt, W.; Lin, F.I.; et al. Brown Adipose Reporting Criteria in Imaging STudies (BARCIST 1.0): Recommendations for Standardized FDG-PET/CT Experiments in Humans. Cell Metab. 2016, 24, $210-222$. [CrossRef] [PubMed]

85. Reichkendler, M.H.; Auerbach, P.; Rosenkilde, M.; Christensen, A.N.; Holm, S.; Petersen, M.B.; Lagerberg, A.; Larsson, H.B.; Rostrup, E.; Mosbech, T.H.; et al. Exercise training favors increased insulin-stimulated glucose uptake in skeletal muscle in contrast to adipose tissue: A randomized study using FDG PET imaging. Am. J. Physiol. Endocrinol. Metab. 2013, 305, E496-E506. [CrossRef] [PubMed]

86. Blondin, D.P.; Labbe, S.M.; Phoenix, S.; Guerin, B.; Turcotte, E.E.; Richard, D.; Carpentier, A.C.; Haman, F. Contributions of white and brown adipose tissues and skeletal muscles to acute cold-induced metabolic responses in healthy men. J. Physiol. 2015, 593, 701-714. [CrossRef] [PubMed]

87. Townsend, K.L.; Tseng, Y.H. Brown fat fuel utilization and thermogenesis. Trends Endocrinol. Metab. 2014, 25, 168-177. [CrossRef] [PubMed]

88. Heeren, J.; Scheja, L. Brown adipose tissue and lipid metabolism. Curr. Opin. Lipidol. 2018, 29, $180-185$. [CrossRef]

89. Wolfe, R.R.; Klein, S.; Carraro, F.; Weber, J.M. Role of triglyceride-fatty acid cycle in controlling fat metabolism in humans during and after exercise. Am. J. Physiol. 1990, 258, E382-E389. [CrossRef]

90. Wu, Z.; Puigserver, P.; Andersson, U.; Zhang, C.; Adelmant, G.; Mootha, V.; Troy, A.; Cinti, S.; Lowell, B.; Scarpulla, R.C.; et al. Mechanisms controlling mitochondrial biogenesis and respiration through the thermogenic coactivator PGC-1. Cell 1999, 98, 115-124. [CrossRef]

91. Medina-Gomez, G. Mitochondria and endocrine function of adipose tissue. Best Pract. Res. Clin. Endocrinol. Metab. 2012, 26, 791-804. [CrossRef]

92. Martins, F.F.; Bargut, T.C.L.; Aguila, M.B.; Mandarim-de-Lacerda, C.A. Thermogenesis, fatty acid synthesis with oxidation, and inflammation in the brown adipose tissue of ob/ob (-/-) mice. Ann. Anat. 2017, 210, 44-51. [CrossRef] [PubMed]

93. Lira, V.A.; Okutsu, M.; Zhang, M.; Greene, N.P.; Laker, R.C.; Breen, D.S.; Hoehn, K.L.; Yan, Z. Autophagy is required for exercise training-induced skeletal muscle adaptation and improvement of physical performance. FASEB J. 2013, 27, 4184-4193. [CrossRef] [PubMed] 
94. Theilen, N.T.; Kunkel, G.H.; Tyagi, S.C. The Role of Exercise and TFAM in Preventing Skeletal Muscle Atrophy. J. Cell Physiol. 2017, 232, 2348-2358. [CrossRef] [PubMed]

95. Vieira, V.J.; Valentine, R.J. Mitochondrial biogenesis in adipose tissue: Can exercise make fat cells 'fit'? J. Physiol. 2009, 587, 3427-3428. [CrossRef] [PubMed]

96. Feigenson, G.W. Phase boundaries and biological membranes. Annu. Rev. Biophys. Biomol. Struct. 2007, 36, 63-77. [CrossRef] [PubMed]

97. Bagatolli, L.A.; Ipsen, J.H.; Simonsen, A.C.; Mouritsen, O.G. An outlook on organization of lipids in membranes: Searching for a realistic connection with the organization of biological membranes. Prog. Lipid Res. 2010, 49, 378-389. [CrossRef] [PubMed]

98. Hoene, M.; Li, J.; Haring, H.U.; Weigert, C.; Xu, G.; Lehmann, R. The lipid profile of brown adipose tissue is sex-specific in mice. Biochim. Biophys. Acta 2014, 1842, 1563-1570. [CrossRef]

99. Senyilmaz, D.; Virtue, S.; Xu, X.; Tan, C.Y.; Griffin, J.L.; Miller, A.K.; Vidal-Puig, A.; Teleman, A.A. Regulation of mitochondrial morphology and function by stearoylation of TFR1. Nature 2015, 525, 124-128. [CrossRef]

100. Bretscher, M.S. Asymmetrical lipid bilayer structure for biological membranes. Nat. New Biol. 1972, 236, 11-12. [CrossRef]

101. Jiang, F.; Ryan, M.T.; Schlame, M.; Zhao, M.; Gu, Z.; Klingenberg, M.; Pfanner, N.; Greenberg, M.L. Absence of cardiolipin in the crd1 null mutant results in decreased mitochondrial membrane potential and reduced mitochondrial function. J. Biol. Chem. 2000, 275, 22387-22394. [CrossRef]

102. Hostetler, K.Y.; van den Bosch, H. Subcellular and submitochondrial localization of the biosynthesis of cardiolipin and related phospholipids in rat liver. Biochim. Biophys. Acta 1972, 260, 380-386. [CrossRef]

103. Faber, C.; Zhu, Z.J.; Castellino, S.; Wagner, D.S.; Brown, R.H.; Peterson, R.A.; Gates, L.; Barton, J.; Bickett, M.; Hagerty, L.; et al. Cardiolipin profiles as a potential biomarker of mitochondrial health in diet-induced obese mice subjected to exercise, diet-restriction and ephedrine treatment. J. Appl. Toxicol. 2014, 34, 1122-1129. [CrossRef]

104. Meikle, P.J.; Summers, S.A. Sphingolipids and phospholipids in insulin resistance and related metabolic disorders. Nat. Rev. Endocrinol. 2017, 13, 79-91. [CrossRef] [PubMed]

105. Mika, A.; Sledzinski, T.; Stepnowski, P. Current progress of lipid analysis in metabolic diseases by mass spectrometry methods. Curr. Med. Chem. 2017. [CrossRef]

106. Senoo, N.; Miyoshi, N.; Goto-Inoue, N.; Minami, K.; Yoshimura, R.; Morita, A.; Sawada, N.; Matsuda, J.; Ogawa, Y.; Setou, M.; et al. PGC-1alpha-mediated changes in phospholipid profiles of exercise-trained skeletal muscle. J. Lipid Res. 2015, 56, 2286-2296. [CrossRef]

107. Lynes, M.D.; Leiria, L.O.; Lundh, M.; Bartelt, A.; Shamsi, F.; Huang, T.L.; Takahashi, H.; Hirshman, M.F.; Schlein, C.; Lee, A.; et al. The cold-induced lipokine 12,13-diHOME promotes fatty acid transport into brown adipose tissue. Nat. Med. 2017, 23, 631-637. [CrossRef] [PubMed]

108. Chartoumpekis, D.V.; Habeos, I.G.; Ziros, P.G.; Psyrogiannis, A.I.; Kyriazopoulou, V.E.; Papavassiliou, A.G. Brown adipose tissue responds to cold and adrenergic stimulation by induction of FGF21. Mol. Med. 2011, 17, 736-740. [CrossRef] [PubMed]

109. Muise, E.S.; Azzolina, B.; Kuo, D.W.; El-Sherbeini, M.; Tan, Y.; Yuan, X.; Mu, J.; Thompson, J.R.; Berger, J.P.; Wong, K.K. Adipose fibroblast growth factor 21 is up-regulated by peroxisome proliferator-activated receptor gamma and altered metabolic states. Mol. Pharmacol. 2008, 74, 403-412. [CrossRef]

110. Hondares, E.; Iglesias, R.; Giralt, A.; Gonzalez, F.J.; Giralt, M.; Mampel, T.; Villarroya, F. Thermogenic activation induces FGF21 expression and release in brown adipose tissue. J. Biol. Chem. 2011, 286, 12983-12990. [CrossRef]

111. Badman, M.K.; Koester, A.; Flier, J.S.; Kharitonenkov, A.; Maratos-Flier, E. Fibroblast growth factor 21-deficient mice demonstrate impaired adaptation to ketosis. Endocrinology 2009, 150, 4931-4940. [CrossRef] [PubMed]

112. Hondares, E.; Rosell, M.; Gonzalez, F.J.; Giralt, M.; Iglesias, R.; Villarroya, F. Hepatic FGF21 expression is induced at birth via PPARalpha in response to milk intake and contributes to thermogenic activation of neonatal brown fat. Cell Metab. 2010, 11, 206-212. [CrossRef] [PubMed]

113. Coskun, T.; Bina, H.A.; Schneider, M.A.; Dunbar, J.D.; Hu, C.C.; Chen, Y.; Moller, D.E.; Kharitonenkov, A. Fibroblast growth factor 21 corrects obesity in mice. Endocrinology 2008, 149, 6018-6027. [CrossRef] [PubMed] 
114. BonDurant, L.D.; Ameka, M.; Naber, M.C.; Markan, K.R.; Idiga, S.O.; Acevedo, M.R.; Walsh, S.A.; Ornitz, D.M.; Potthoff, M.J. FGF21 Regulates Metabolism Through Adipose-Dependent and -Independent Mechanisms. Cell Metab. 2017, 25, 935-944.e934. [CrossRef] [PubMed]

115. Schlein, C.; Talukdar, S.; Heine, M.; Fischer, A.W.; Krott, L.M.; Nilsson, S.K.; Brenner, M.B.; Heeren, J.; Scheja, L. FGF21 Lowers Plasma Triglycerides by Accelerating Lipoprotein Catabolism in White and Brown Adipose Tissues. Cell Metab. 2016, 23, 441-453. [CrossRef] [PubMed]

116. Xu, J.; Lloyd, D.J.; Hale, C.; Stanislaus, S.; Chen, M.; Sivits, G.; Vonderfecht, S.; Hecht, R.; Li, Y.S.; Lindberg, R.A.; et al. Fibroblast growth factor 21 reverses hepatic steatosis, increases energy expenditure, and improves insulin sensitivity in diet-induced obese mice. Diabetes 2009, 58, 250-259. [CrossRef] [PubMed]

117. Xu, J.; Stanislaus, S.; Chinookoswong, N.; Lau, Y.Y.; Hager, T.; Patel, J.; Ge, H.; Weiszmann, J.; Lu, S.C.; Graham, M.; et al. Acute glucose-lowering and insulin-sensitizing action of FGF21 in insulin-resistant mouse models-association with liver and adipose tissue effects. Am. J. Physiol. Endocrinol. Metab. 2009, 297, E1105-E1114. [CrossRef] [PubMed]

118. Keipert, S.; Kutschke, M.; Ost, M.; Schwarzmayr, T.; van Schothorst, E.M.; Lamp, D.; Brachthauser, L.; Hamp, I.; Mazibuko, S.E.; Hartwig, S.; et al. Long-Term Cold Adaptation Does Not Require FGF21 or UCP1. Cell Metab. 2017, 26, 437-446.e435. [CrossRef]

119. Di Franco, A.; Guasti, D.; Squecco, R.; Mazzanti, B.; Rossi, F.; Idrizaj, E.; Gallego-Escuredo, J.M.; Villarroya, F.; Bani, D.; Forti, G.; et al. Searching for Classical Brown Fat in Humans: Development of a Novel Human Fetal Brown Stem Cell Model. Stem Cells 2016, 34, 1679-1691. [CrossRef]

120. Lee, P.; Brychta, R.J.; Linderman, J.; Smith, S.; Chen, K.Y.; Celi, F.S. Mild cold exposure modulates fibroblast growth factor 21 (FGF21) diurnal rhythm in humans: Relationship between FGF21 levels, lipolysis, and cold-induced thermogenesis. J. Clin. Endocrinol. Metab. 2013, 98, E98-E102. [CrossRef]

121. Hanssen, M.J.; Broeders, E.; Samms, R.J.; Vosselman, M.J.; van der Lans, A.A.; Cheng, C.C.; Adams, A.C.; van Marken Lichtenbelt, W.D.; Schrauwen, P. Serum FGF21 levels are associated with brown adipose tissue activity in humans. Sci. Rep. 2015, 5, 10275. [CrossRef]

122. Lee, P.; Linderman, J.D.; Smith, S.; Brychta, R.J.; Wang, J.; Idelson, C.; Perron, R.M.; Werner, C.D.; Phan, G.Q.; Kammula, U.S.; et al. Irisin and FGF21 are cold-induced endocrine activators of brown fat function in humans. Cell Metab. 2014, 19, 302-309. [CrossRef] [PubMed]

123. Kim, K.H.; Kim, S.H.; Min, Y.K.; Yang, H.M.; Lee, J.B.; Lee, M.S. Acute exercise induces FGF21 expression in mice and in healthy humans. PLoS ONE 2013, 8, e63517. [CrossRef] [PubMed]

124. Cuevas-Ramos, D.; Almeda-Valdes, P.; Meza-Arana, C.E.; Brito-Cordova, G.; Gomez-Perez, F.J.; Mehta, R.; Oseguera-Moguel, J.; Aguilar-Salinas, C.A. Exercise increases serum fibroblast growth factor 21 (FGF21) levels. PLOS ONE 2012, 7, e38022. [CrossRef] [PubMed]

125. Talukdar, S.; Zhou, Y.; Li, D.; Rossulek, M.; Dong, J.; Somayaji, V.; Weng, Y.; Clark, R.; Lanba, A.; Owen, B.M.; et al. A Long-Acting FGF21 Molecule, PF-05231023, Decreases Body Weight and Improves Lipid Profile in Non-human Primates and Type 2 Diabetic Subjects. Cell Metab. 2016, 23, 427-440. [CrossRef] [PubMed]

126. Neufeld, G.; Cohen, T.; Gengrinovitch, S.; Poltorak, Z. Vascular endothelial growth factor (VEGF) and its receptors. FASEB J. 1999, 13, 9-22. [CrossRef] [PubMed]

127. Mahdaviani, K.; Chess, D.; Wu, Y.; Shirihai, O.; Aprahamian, T.R. Autocrine effect of vascular endothelial growth factor-A is essential for mitochondrial function in brown adipocytes. Metabolism 2016, 65, 26-35. [CrossRef] [PubMed]

128. Ludzki, A.C.; Pataky, M.W.; Cartee, G.D.; Horowitz, J.F. Acute endurance exercise increases Vegfa mRNA expression in adipose tissue of rats during the early stages of weight gain. Appl. Physiol. Nutr. Metab. Physiol. Appl. Nutr. Metab. 2018, 43, 751-754. [CrossRef] [PubMed]

129. Stanford, K.I.; Middelbeek, R.J.; Townsend, K.L.; Lee, M.Y.; Takahashi, H.; So, K.; Hitchcox, K.M.; Markan, K.R.; Hellbach, K.; Hirshman, M.F.; et al. A novel role for subcutaneous adipose tissue in exerciseinduced improvements in glucose homeostasis. Diabetes 2015, 64, 2002-2014. [CrossRef] [PubMed]

130. Van Pelt, D.W.; Guth, L.M.; Horowitz, J.F. Aerobic exercise elevates markers of angiogenesis and macrophage IL-6 gene expression in the subcutaneous adipose tissue of overweight-to-obese adults. J. Appl. Physiol. (Bethesda, Md. 1985) 2017, 123, 1150-1159. [CrossRef] [PubMed]

131. Kraus, R.M.; Stallings, H.W., 3rd; Yeager, R.C.; Gavin, T.P. Circulating plasma VEGF response to exercise in sedentary and endurance-trained men. J. Appl. Physiol. (Bethesda, Md. 1985) 2004, 96, 1445-1450. [CrossRef]

132. Ishibashi, J.; Seale, P. Medicine. Beige can be slimming. Science (N. Y.) 2010, 328, 1113-1114. [CrossRef] 
133. Bartelt, A.; Heeren, J. Adipose tissue browning and metabolic health. Nat. Rev. Endocrinol. 2014, 10, $24-36$. [CrossRef] [PubMed]

134. Vargas-Castillo, A.; Fuentes-Romero, R.; Rodriguez-Lopez, L.A.; Torres, N.; Tovar, A.R. Understanding the Biology of Thermogenic Fat: Is Browning A New Approach to the Treatment of Obesity? Arch. Med. Res. 2017, 48, 401-413. [CrossRef]

135. Seale, P.; Bjork, B.; Yang, W.; Kajimura, S.; Chin, S.; Kuang, S.; Scime, A.; Devarakonda, S.; Conroe, H.M.; Erdjument-Bromage, H.; et al. PRDM16 controls a brown fat/skeletal muscle switch. Nature 2008, 454, 961-967. [CrossRef]

136. Wu, J.; Bostrom, P.; Sparks, L.M.; Ye, L.; Choi, J.H.; Giang, A.H.; Khandekar, M.; Virtanen, K.A.; Nuutila, P.; Schaart, G.; et al. Beige adipocytes are a distinct type of thermogenic fat cell in mouse and human. Cell 2012, 150, 366-376. [CrossRef]

137. Montanari, T.; Poscic, N.; Colitti, M. Factors involved in white-to-brown adipose tissue conversion and in thermogenesis: A review. Obes. Rev. Off. J. Int. Assoc. Stud. Obes. 2017, 18, 495-513. [CrossRef] [PubMed]

138. Kiefer, F.W. The significance of beige and brown fat in humans. Endocr. Connect. 2017, 6, R70-R79. [CrossRef] [PubMed]

139. Lee, P.; Swarbrick, M.M.; Zhao, J.T.; Ho, K.K. Inducible brown adipogenesis of supraclavicular fat in adult humans. Endocrinology 2011, 152, 3597-3602. [CrossRef] [PubMed]

140. Cypess, A.M.; White, A.P.; Vernochet, C.; Schulz, T.J.; Xue, R.; Sass, C.A.; Huang, T.L.; Roberts-Toler, C.; Weiner, L.S.; Sze, C.; et al. Anatomical localization, gene expression profiling and functional characterization of adult human neck brown fat. Nat. Med. 2013, 19, 635-639. [CrossRef] [PubMed]

141. Jespersen, N.Z.; Larsen, T.J.; Peijs, L.; Daugaard, S.; Homoe, P.; Loft, A.; de Jong, J.; Mathur, N.; Cannon, B.; Nedergaard, J.; et al. A classical brown adipose tissue mRNA signature partly overlaps with brite in the supraclavicular region of adult humans. Cell Metab. 2013, 17, 798-805. [CrossRef]

142. Shinoda, K.; Luijten, I.H.; Hasegawa, Y.; Hong, H.; Sonne, S.B.; Kim, M.; Xue, R.; Chondronikola, M.; Cypess, A.M.; Tseng, Y.H.; et al. Genetic and functional characterization of clonally derived adult human brown adipocytes. Nat. Med. 2015, 21, 389-394. [CrossRef] [PubMed]

143. Sidossis, L.; Kajimura, S. Brown and beige fat in humans: Thermogenic adipocytes that control energy and glucose homeostasis. J. Clin. Investig. 2015, 125, 478-486. [CrossRef] [PubMed]

144. Petrovic, N.; Walden, T.B.; Shabalina, I.G.; Timmons, J.A.; Cannon, B.; Nedergaard, J. Chronic peroxisome proliferator-activated receptor gamma (PPARgamma) activation of epididymally derived white adipocyte cultures reveals a population of thermogenically competent, UCP1-containing adipocytes molecularly distinct from classic brown adipocytes. J. Biol. Chem. 2010, 285, 7153-7164. [CrossRef] [PubMed]

145. Nedergaard, J.; Cannon, B. The browning of white adipose tissue: Some burning issues. Cell Metab. 2014, 20, 396-407. [CrossRef] [PubMed]

146. Villarroya, F.; Cereijo, R.; Villarroya, J.; Giralt, M. Brown adipose tissue as a secretory organ. Nat. Rev. Endocrinol. 2017, 13, 26-35. [CrossRef] [PubMed]

147. Christian, M. Transcriptional fingerprinting of "browning" white fat identifies NRG4 as a novel adipokine. Adipocyte 2015, 4, 50-54. [CrossRef] [PubMed]

148. Fisher, F.M.; Kleiner, S.; Douris, N.; Fox, E.C.; Mepani, R.J.; Verdeguer, F.; Wu, J.; Kharitonenkov, A.; Flier, J.S.; Maratos-Flier, E.; et al. FGF21 regulates PGC-1alpha and browning of white adipose tissues in adaptive thermogenesis. Genes Dev. 2012, 26, 271-281. [CrossRef]

149. Zhang, Y.; Xie, C.; Wang, H.; Foss, R.M.; Clare, M.; George, E.V.; Li, S.; Katz, A.; Cheng, H.; Ding, Y.; et al. Irisin exerts dual effects on browning and adipogenesis of human white adipocytes. Am. J. Physiol. Endocrinol. Metab. 2016, 311, E530-E541. [CrossRef]

150. Hu, J.; Christian, M. Hormonal factors in the control of the browning of white adipose tissue. Horm. Mol. Biol. Clin. Investig. 2017, 31. [CrossRef]

151. Bargut, T.C.L.; Souza-Mello, V.; Aguila, M.B.; Mandarim-de-Lacerda, C.A. Browning of white adipose tissue: Lessons from experimental models. Horm. Mol. Biol. Clin. Investig. 2017, 31. [CrossRef]

152. Pyrzak, B.; Demkow, U.; Kucharska, A.M. Brown Adipose Tissue and Browning Agents: Irisin and FGF21 in the Development of Obesity in Children and Adolescents. Adv. Exp. Med. Biol. 2015, 866, 25-34. [CrossRef] [PubMed] 
153. Chaurasia, B.; Kaddai, V.A.; Lancaster, G.I.; Henstridge, D.C.; Sriram, S.; Galam, D.L.; Gopalan, V.; Prakash, K.N.; Velan, S.S.; Bulchand, S.; et al. Adipocyte Ceramides Regulate Subcutaneous Adipose Browning, Inflammation, and Metabolism. Cell Metab. 2016, 24, 820-834. [CrossRef] [PubMed]

154. Yao, L.; Cui, X.; Chen, Q.; Yang, X.; Fang, F.; Zhang, J.; Liu, G.; Jin, W.; Chang, Y. Cold-Inducible SIRT6 Regulates Thermogenesis of Brown and Beige Fat. Cell Rep. 2017, 20, 641-654. [CrossRef] [PubMed]

155. Hui, X.; Gu, P.; Zhang, J.; Nie, T.; Pan, Y.; Wu, D.; Feng, T.; Zhong, C.; Wang, Y.; Lam, K.S.; et al. Adiponectin Enhances Cold-Induced Browning of Subcutaneous Adipose Tissue via Promoting M2 Macrophage Proliferation. Cell Metab. 2015, 22, 279-290. [CrossRef] [PubMed]

156. Rosell, M.; Kaforou, M.; Frontini, A.; Okolo, A.; Chan, Y.W.; Nikolopoulou, E.; Millership, S.; Fenech, M.E.; MacIntyre, D.; Turner, J.O.; et al. Brown and white adipose tissues: Intrinsic differences in gene expression and response to cold exposure in mice. Am. J. Physiol. Endocrinol. Metab. 2014, 306, E945-E964. [CrossRef] [PubMed]

157. Paschos, G.K.; Tang, S.Y.; Theken, K.N.; Li, X.; Verginadis, I.; Lekkas, D.; Herman, L.; Yan, W.; Lawson, J.; FitzGerald, G.A. Cold-Induced Browning of Inguinal White Adipose Tissue Is Independent of Adipose Tissue Cyclooxygenase-2. Cell Rep. 2018, 24, 809-814. [CrossRef] [PubMed]

158. Finlin, B.S.; Zhu, B.; Confides, A.L.; Westgate, P.M.; Harfmann, B.D.; Dupont-Versteegden, E.E.; Kern, P.A. Mast Cells Promote Seasonal White Adipose Beiging in Humans. Diabetes 2017, 66, 1237-1246. [CrossRef] [PubMed]

159. Kern, P.A.; Finlin, B.S.; Zhu, B.; Rasouli, N.; McGehee, R.E., Jr.; Westgate, P.M.; Dupont-Versteegden, E.E. The effects of temperature and seasons on subcutaneous white adipose tissue in humans: Evidence for thermogenic gene induction. J. Clin. Endocrinol. Metab. 2014, 99, E2772-E2779. [CrossRef]

160. van der Lans, A.A.; Hoeks, J.; Brans, B.; Vijgen, G.H.; Visser, M.G.; Vosselman, M.J.; Hansen, J.; Jorgensen, J.A.; $\mathrm{Wu}$, J.; Mottaghy, F.M.; et al. Cold acclimation recruits human brown fat and increases nonshivering thermogenesis. J. Clin. Investig. 2013, 123, 3395-3403. [CrossRef]

161. Tsiloulis, T.; Watt, M.J. Exercise and the Regulation of Adipose Tissue Metabolism. Prog. Mol. Biol. Transl. Sci. 2015, 135, 175-201. [CrossRef]

162. Bostrom, P.; Wu, J.; Jedrychowski, M.P.; Korde, A.; Ye, L.; Lo, J.C.; Rasbach, K.A.; Bostrom, E.A.; Choi, J.H.; Long, J.Z.; et al. A PGC1-alpha-dependent myokine that drives brown-fat-like development of white fat and thermogenesis. Nature 2012, 481, 463-468. [CrossRef] [PubMed]

163. Knudsen, J.G.; Murholm, M.; Carey, A.L.; Bienso, R.S.; Basse, A.L.; Allen, T.L.; Hidalgo, J.; Kingwell, B.A.; Febbraio, M.A.; Hansen, J.B.; et al. Role of IL-6 in exercise training- and cold-induced UCP1 expression in subcutaneous white adipose tissue. PLoS ONE 2014, 9, e84910. [CrossRef] [PubMed]

164. Rao, R.R.; Long, J.Z.; White, J.P.; Svensson, K.J.; Lou, J.; Lokurkar, I.; Jedrychowski, M.P.; Ruas, J.L.; Wrann, C.D.; Lo, J.C.; et al. Meteorin-like is a hormone that regulates immune-adipose interactions to increase beige fat thermogenesis. Cell 2014, 157, 1279-1291. [CrossRef] [PubMed]

165. Bae, J.Y. Aerobic Exercise Increases Meteorin-Like Protein in Muscle and Adipose Tissue of Chronic High-Fat Diet-Induced Obese Mice. BioMed Res. Int. 2018, 2018, 6283932. [CrossRef] [PubMed]

166. Dewal, R.S.; Stanford, K.I. Effects of exercise on brown and beige adipocytes. Biochim. Biophys. Acta Mol. Cell Biol. Lipids 2019, 1864, 71-78. [CrossRef] [PubMed]

167. Cao, L.; Choi, E.Y.; Liu, X.; Martin, A.; Wang, C.; Xu, X.; During, M.J. White to brown fat phenotypic switch induced by genetic and environmental activation of a hypothalamic-adipocyte axis. Cell Metab. 2011, 14, 324-338. [CrossRef] [PubMed]

168. Schaalan, M.F.; Ramadan, B.K.; Abd Elwahab, A.H. Synergistic effect of carnosine on browning of adipose tissue in exercised obese rats; a focus on circulating irisin levels. J. Cell. Physiol. 2018, 233, 5044-5057. [CrossRef]

169. Davis, R.A.H.; Halbrooks, J.E.; Watkins, E.E.; Fisher, G.; Hunter, G.R.; Nagy, T.R.; Plaisance, E.P. High-intensity interval training and calorie restriction promote remodeling of glucose and lipid metabolism in diet-induced obesity. Am. J. Physiol. Endocrinol. Metab. 2017, 313, E243-E256. [CrossRef]

170. Shirkhani, S.; Marandi, S.M.; Kazeminasab, F.; Esmaeili, M.; Ghaedi, K.; Esfarjani, F.; Shiralian-Esfahani, H.; Nasr-Esfahani, M.H. Comparative studies on the effects of high-fat diet, endurance training and obesity on Ucp1 expression in male C57BL/6 mice. Gene 2018, 676, 16-21. [CrossRef] 
171. Norheim, F.; Langleite, T.M.; Hjorth, M.; Holen, T.; Kielland, A.; Stadheim, H.K.; Gulseth, H.L.; Birkeland, K.I.; Jensen, J.; Drevon, C.A. The effects of acute and chronic exercise on PGC-1alpha, irisin and browning of subcutaneous adipose tissue in humans. FEBS J. 2014, 281, 739-749. [CrossRef]

172. Camera, D.M.; Anderson, M.J.; Hawley, J.A.; Carey, A.L. Short-term endurance training does not alter the oxidative capacity of human subcutaneous adipose tissue. Eur. J. Appl. Physiol. 2010, 109, 307-316. [CrossRef] [PubMed]

173. Tsiloulis, T.; Carey, A.L.; Bayliss, J.; Canny, B.; Meex, R.C.R.; Watt, M.J. No evidence of white adipocyte browning after endurance exercise training in obese men. Int. J. Obes. (2005) 2018, 42, 721-727. [CrossRef] [PubMed]

174. Nakhuda, A.; Josse, A.R.; Gburcik, V.; Crossland, H.; Raymond, F.; Metairon, S.; Good, L.; Atherton, P.J.; Phillips, S.M.; Timmons, J.A. Biomarkers of browning of white adipose tissue and their regulation during exercise- and diet-induced weight loss. Am. J. Clin. Nutr. 2016, 104, 557-565. [CrossRef] [PubMed]

175. Otero-Diaz, B.; Rodriguez-Flores, M.; Sanchez-Munoz, V.; Monraz-Preciado, F.; Ordonez-Ortega, S.; Becerril-Elias, V.; Baay-Guzman, G.; Obando-Monge, R.; Garcia-Garcia, E.; Palacios-Gonzalez, B.; et al. Exercise Induces White Adipose Tissue Browning Across the Weight Spectrum in Humans. Front. Physiol. 2018, 9, 1781. [CrossRef] [PubMed]

176. Stevens, C.J.; Taylor, L.; Dascombe, B.J. Cooling During Exercise: An Overlooked Strategy for Enhancing Endurance Performance in the Heat. Sports Med. (Auckland, N.Z.) 2017, 47, 829-841. [CrossRef] [PubMed]

177. Sebastian, J.C. Respiratory physiology and pulmonary complications in obesity. Best Pract. Res. Clin Endocrinol. Metab. 2013, 27, 157-161. [CrossRef] [PubMed]

178. Lavie, C.J.; McAuley, P.A.; Church, T.S.; Milani, R.V.; Blair, S.N. Obesity and cardiovascular diseases: Implications regarding fitness, fatness, and severity in the obesity paradox. J. Am. Coll. Cardiol. 2014, 63, 1345-1354. [CrossRef]

(C) 2019 by the authors. Licensee MDPI, Basel, Switzerland. This article is an open access article distributed under the terms and conditions of the Creative Commons Attribution (CC BY) license (http://creativecommons.org/licenses/by/4.0/). 